\title{
Flux dynamics of planktic foraminiferal tests in the south-eastern Bay of Biscay (northeast Atlantic margin)
}

\author{
Tanja Kuhnt ${ }^{\mathrm{a}, 1}$, Hélène Howa ${ }^{\mathrm{a}, *}$, Sabine Schmidt ${ }^{\mathrm{b}}$, Louis Marié ${ }^{\mathrm{c}}$, Ralf Schiebel ${ }^{\mathrm{a}}$ \\ a Laboratory of Recent and Fossil Bio-Indicators (BIAF), University of Angers, UPRES EA 2644, 2 Boulevard Lavoisier, 49045 Angers Cedex, France \\ b EPOC, UMR 5805 CNRS, Avenue des Facultés, 33405 Talence Cedex, France \\ c LPO, UMR 6523 CNRS/IFREMER/IRD/UBO, IFREMER / Centre de Brest, 29280 Plouzané, France
}

\section{A R T I C L E I N F O}

\section{Article history:}

Received 14 September 2010

Received in revised form 7 November 2011

Accepted 30 November 2011

Available online 14 December 2011

\section{Keywords:}

Planktic foraminifera

Bay of Biscay

Sediment traps

Particulate mass flux

${ }^{210} \mathrm{~Pb}$

Seasonality

Lateral advection

\begin{abstract}
A B S T R A C T
The temporal and water depth related dynamics of planktic foraminiferal fluxes in the south-eastern Bay of Biscay are discussed for a two year sampling period (June 2006-June 2008). Two sediment traps deployed at $800 \mathrm{~m}$ and $1700 \mathrm{~m}$ water depth at a mooring in $2000 \mathrm{~m}$ of water depth, were analyzed for the flux of planktic foraminiferal species $>150 \mu \mathrm{m}$, in comparison with the total mass flux. Total flux of planktic foraminifera shows seasonal maxima in spring/early summer $\left(>2000\right.$ Ind. $\left.\mathrm{m}^{-2} \mathrm{~d}^{-1}\right)$ and minima from late summer through winter $\left(<10\right.$ Ind. $\left.\mathrm{m}^{-2} \mathrm{~d}^{-1}\right)$. The flux of planktic foraminiferal tests in the intermediate to deep water column at the inner Bay of Biscay comprises an intermittent and regionally variable signal of seasonal surface water primary productivity. Significant lateral transport and flux of particles superimposed on the downward mass flux indicate a decoupling of fluxes between the $800-\mathrm{m}$ and $1700-\mathrm{m}$ traps. The ${ }^{210} \mathrm{~Pb}$ budget and the presence of certain benthic foraminiferal species in the midwater column prove that the lateral flux originated from the upper continental slope. Despite the temporal and vertical variations of the particulate flux, a well-defined seasonal flux signal can be deduced from the frequency of planktic foraminiferal species. (c) 2011 Elsevier B.V. All rights reserved.
\end{abstract}

\section{Introduction}

Planktic foraminifera constitute a major group of the calcareous marine microplankton. Due to their high sensitivity to varying sea surface conditions and preservation of their calcareous tests in sedimentary archives, they are one of the most frequently applied microfossil groups in paleoceanography (e.g. Kucera, 2007). Many regions of the world oceans have been investigated in order to contribute to a broad understanding of the ecology of planktic foraminifera (e.g. Bé, 1960, 1977; Bé and Tolderlund, 1971; Fairbanks et al., 1982; Hemleben et al., 1989; Schiebel and Hemleben, 2005; Tolderlund and Bé, 1971, and references therein).

The use of sediment traps provides the opportunity to continuously record variations in production and flux of planktic foraminifera and contributes to a better understanding of past oceanographic changes. Previous trap studies revealed seasonal and interannual variations in abundance and flux of planktic foraminifera, which were related to food availability and changes in sea surface temperature (Abrantes et al., 2002; Bárcena et al., 2004; Deuser et al., 1981; Schiebel, 2002; Thunell and Honjo, 1987). The few studies which have been carried

\footnotetext{
* Corresponding author. Tel.: + 332417353 80; fax: + 33241735352.

E-mail address: helene.howa@univ-angers.fr (H. Howa).

${ }^{1}$ Present address: Institute of Geosciences, Frankfurt University, Altenhöferallee 1, 60438 Frankfurt, Germany.
}

out on planktic foraminiferal fluxes in hemipelagic environments (Brunner and Biscaye, 2003; Ortiz et al., 1995), are often focused on upwelling regions (Marchant et al., 1998, 2004; Mohtadi et al., 2009; Reynolds and Thunell, 1989). Thus, the factors controlling the production and flux of planktic foraminifera on a continental margin not affected by upwelling remain poorly understood.

Previous studies of particle flux dynamics at continental margins have shown that processes of sediment reworking and transport in suspension play an important role in the redistribution of particles, including foraminiferal tests (Biscaye et al., 1988, 1994; Hwang et al., 2009; Thomsen and van Weering, 1998). Observations of stormdriven resuspension of planktic foraminiferal tests were made at the shelf break of the southern Middle Atlantic Bight (Brunner and Biscaye, 1997, 2003). Entrainment and lateral transport of particles including planktic foraminifera is a prevalent feature along the French continental margin in the Bay of Biscay (Durrieu de Madron et al., 1999; Heussner et al., 1999; Radakovitch and Heussner, 1999; Schmidt et al., 2009).

The present work aims to evaluate the export of planktic foraminiferal tests through the water column towards the seabed, and to discriminate downward flux from lateral advection of planktic foraminifera. We discuss planktic foraminiferal flux in comparison to total mass flux and ${ }^{210} \mathrm{~Pb}$ flux over a two year period, in order to understand the flux dynamics of planktic foraminifera in a hemipelagic mid-latitude region in the Bay of Biscay. Our aim is to determine the seasonal surface water signal of planktic foraminiferal production transmitted at depth, 
in order to properly interpret the foraminiferal assemblages in sedimentary archives as a proxy of for past oceanographic changes.

\section{Environmental setting}

\subsection{Hydrography}

The Bay of Biscay is a semi-enclosed mid-latitude basin in the eastern North Atlantic Ocean (Fig. 1). In the central Bay of Biscay, surface water circulation exhibits a weak anticyclonic pattern on average, accompanied by cyclonic and anticyclonic eddies (Pingree and Le Cann, 1992). Along the continental slope, surface waters are predominately influenced by the Iberian Poleward Current (Navidad Current), which enters the southern Bay of Biscay from the Galician margin (Durrieu de Madron et al., 1999; Haynes and Barton, 1990; Pingree and Le Cann, 1990). This poleward transport of warm and saline surface waters is particularly intense during winter, with occasional reversals in direction during summer (Durrieu de Madron et al., 1999; van Aken, 2000).

Below the surface mixed layer ( $200 \mathrm{~m}$ water depth), low saline ( 35.51-35.54) Eastern North Atlantic Central Water (ENACW) is present down to $600 \mathrm{~m}$ water depth. Between $600 \mathrm{~m}$ and $1300 \mathrm{~m}$, the Mediterranean Outflow Water (MOW) is characterized by high salinity ( 35.73-35.76) and fairly low oxygen concentration (Fig. 1c). Below the MOW, the Northeast Atlantic Deep Water (NEADW) occurs to about $3000 \mathrm{~m}$ water depth (e.g. Durrieu de Madron et al., 1999).

In the Bay of Biscay, thermocline depth and strength are marked by pronounced seasonal variations (Puillat et al., 2004). Thermal stratification occurs between May and mid-September, resulting in a seasonal thermocline at about $50 \mathrm{~m}$ depth. Progressive breakdown of the thermocline in fall is caused by cooling and wind-induced vertical mixing of the surface ocean. From January to early April, the upper water column remains homogenous. Haline stratification occurs between April and June, and is related to high river runoff and relatively weak vertical mixing. In fall, haline stratification decreases due to low river discharge and wind-induced vertical mixing.

The south-eastern Bay of Biscay is affected by freshwater discharge from the Gironde and Adour rivers, with annual mean discharges of $\sim 1100 \mathrm{~m}^{3} \mathrm{~s}^{-1}$ (Schäfer et al., 2002) and $\sim 350 \mathrm{~m}^{3} \mathrm{~s}^{-1}$ (Brunet and Astin, 1999), respectively. The Gironde river $\sim 150 \mathrm{~km}$ to the northeast of the sampling site has a maximum discharge of $6700 \mathrm{~m}^{3} \mathrm{~s}^{-1}$ in winter and spring, and a minimum of $\sim 100 \mathrm{~m}^{3} \mathrm{~s}^{-1}$ in summer (Schäfer et al., 2002). Little is known about the annual variation of the Adour discharge, but a seasonal variability was expected by Coynel et al. (2005), and enhanced discharges of the Adour River were recorded in winter and spring, varying around $1000 \mathrm{~m}^{3} \mathrm{~s}^{-1}$ (Gil and Sanchez, 2000). The freshwater plumes commonly spread northwards along the French coast driven by wind and density currents (Lazure and Jegou, 1998; Puillat et al., 2004), but the prevailing wind direction may affect the spreading direction of the plume (Froidefond et al., 2002, and references therein). The increased river-runoff leads to enhanced nutrient supply in surface waters, which can trigger primary production (Fernandez et al., 1991).

\subsection{Primary production}

The Bay of Biscay is oligotrophic to mesotrophic and is characterized by seasonal variation in productivity. Major plankton productivity occurs during spring and a secondary peak in primary production occasionally occurs in fall. In winter, wind-driven mixing of the water column leads to enhanced nutrient supply in the surface waters but due to light limitation primary production remains slow (Antoine et al., 1996; Obata et al., 1996). In spring, maximum phytoplankton productivity is associated with high nutrient availability and increasing light levels (Antoine et al., 1996; Laborde et al., 1999; Tréguer et al., 1979). For the spring bloom of 1973, Tréguer et al. (1979) estimated primary production between 0.4 and $1.9 \mathrm{~g} \mathrm{C} \mathrm{m}^{-2} \mathrm{~d}^{-1}$. Primary production in the Cap Ferret region in May 1990 and 1991 varied between 1 and $1.5 \mathrm{~g} \mathrm{C} \mathrm{m}^{-2} \mathrm{~d}^{-1}$ (Laborde et al., 1999). During summer, chlorophyll- $a$ is concentrated at the bottom of the photic zone, near the pycnocline caused by a strong thermal stratification of the surface waters (Laborde et al., 1999). Fall plankton production is generally less pronounced than spring production, and in part due to the progressive breakdown of the summer thermocline. Measurements of primary production showed values from 0.3 to $0.4 \mathrm{~g} \mathrm{C} \mathrm{m}^{-2} \mathrm{~d}^{-1}$ for the central Bay of Biscay in fall 1972 (Le Corre and Tréguer, 1976), and of $0.3 \mathrm{~g} \mathrm{C} \mathrm{m}^{-2} \mathrm{~d}^{-1}$ for the Cap Ferret region in October 1990 (Laborde et al., 1999). The annual primary production has been estimated to be about $180 \mathrm{~g} \mathrm{C} \mathrm{m}^{-2} \mathrm{y}^{-1}$ by Antoine et al. (1996) and between 145 and $170 \mathrm{~g} \mathrm{C} \mathrm{m}^{-2} \mathrm{y}^{-1}$ by Laborde et al. (1999).

In general, phytoplankton assemblages are dominated by prymnesiophytes (mainly coccolithophores). Coccolithophores are present throughout the year and show a seasonal succession (Beaufort and Heussner, 2001; Wollast and Chou, 2001). During bloom events, phytoplankton assemblages are commonly dominated by diatoms, silicoflagellates, and coccolithophores (Beaufort and Heussner, 2001; Lampert et al., 2002; Tréguer et al., 1979). Minor upwelling events have been observed in
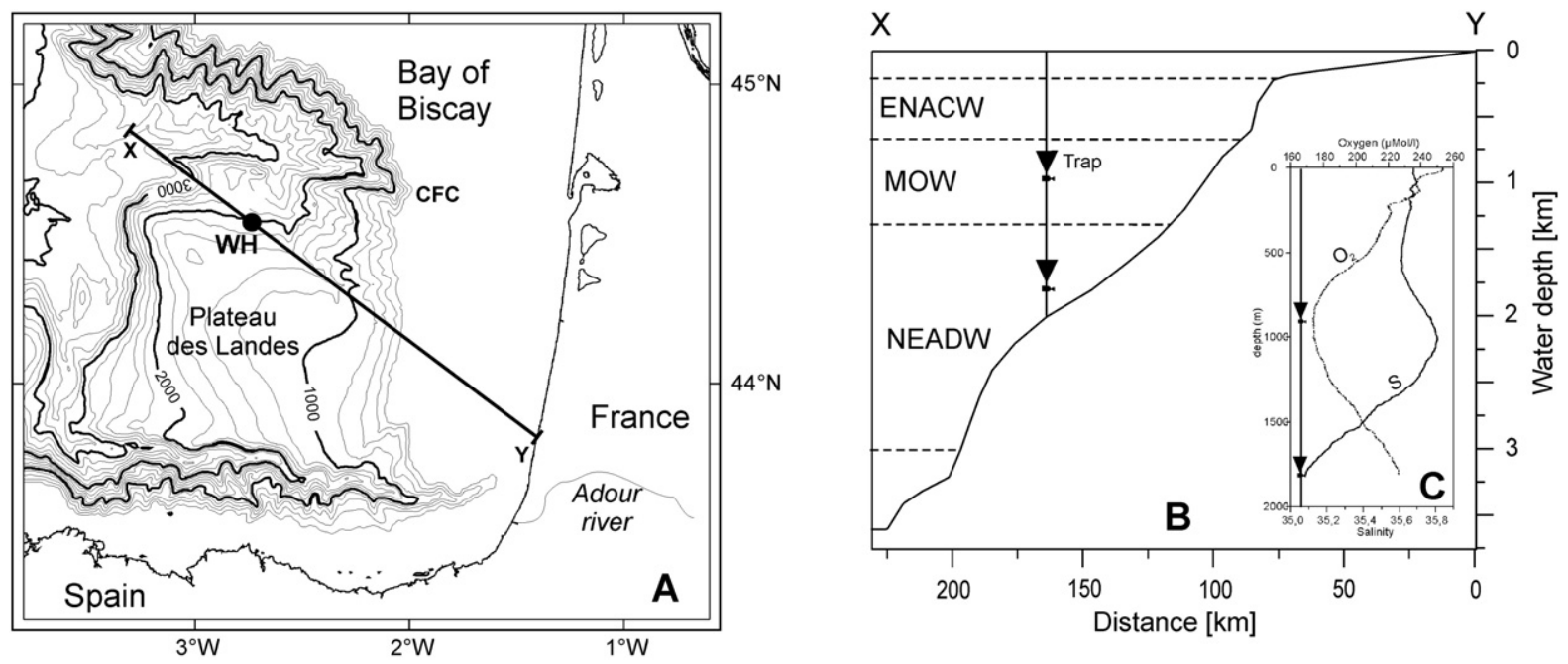

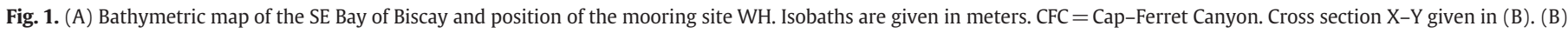

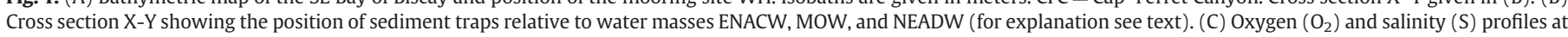
station WH measured in April 2007. 
summer (Froidefond et al., 1996), resulting in large coccolithophore blooms (Beaufort and Heussner, 2001; Fernandez et al., 1993).

\section{Material and methods}

\subsection{Collection of samples and data}

The mooring Station WH was located on the French continental slope in the south-eastern Bay of Biscay $\left(44^{\circ} 33^{\prime} \mathrm{N}, 2^{\circ} 45^{\prime} \mathrm{W}\right)$ at $2000 \mathrm{~m}$ water depth (Fig. 1). The mooring was equipped with two conical sediment traps (PPS5 TECHNICAP, sampling area $1 \mathrm{~m}^{2}, 24$ receiving cups) deployed at about $300 \mathrm{~m}$ and $1200 \mathrm{~m}$ above the seafloor, i.e., at $1700 \mathrm{~m}$ and $800 \mathrm{~m}$ water depth. The mooring was deployed over a two year period (June 2006-June 2008), with three consecutive deployment periods: from 22 June 2006 to 6 April 2007, 16 April to 23 November 2007, and 25 November 2007 to 27 June 2008.

Each trap was equipped with an inclinometer and a current meter. Data collected by the inclinometers show that traps remained vertical $\left(0^{\circ}+/-2.5^{\circ}\right)$ over the two year deployment. The Aanderaa RCM 8 rotor current meter used during the first deployment at $800 \mathrm{~m}$ depth provided satisfactory data. A rotor-based MORS current meter deployed at $1700 \mathrm{~m}$ depth did not function properly. During the second and third deployment periods, both $800 \mathrm{~m}$ and $1700 \mathrm{~m}$ measurement levels were equipped with Nortek Aquadopp acoustic current meters, which worked well.

Samples were collected at 5- to 12-day sampling intervals (Tables 1 and 2). Due to a technical problem, material collection stopped after 20 July 2007 at $800 \mathrm{~m}$ water depth. Prior to mooring, sample cups were filled with $0.45-\mu \mathrm{m}$ filtered and poisoned $(50 \mathrm{~g}$ $\mathrm{NaN}_{3} \mathrm{l}^{-1}$ ) seawater (collected at depth) in order to prevent degradation of samples. Samples were stored in the dark at $4{ }^{\circ} \mathrm{C}$ after recovery of the traps.

\subsection{Processing of samples}

After removing zooplankton "swimmers", samples were precisely divided into two equal aliquots using a rotary liquid splitter (Folsom's Plankton Sample Divider @ HYDRO BIOS) with a precision of $>95 \%$, following the method of Lončarić et al. (2007). Aliquots for foraminiferal analyses from the first collection period (June 2006 to March 2007, both water depths) were wet sieved over a $100-\mu \mathrm{m}$ mesh, rinsed with ethanol, and ashed in a low temperature-asher. Aliquots of the following sampling periods were also wet sieved over a $100-\mu \mathrm{m}$ mesh, and dried at $50{ }^{\circ} \mathrm{C}$. Dry samples were sieved at $100 \mu \mathrm{m}, 150 \mu \mathrm{m}$ and $250 \mu \mathrm{m}$. Analysis of the planktic foraminiferal fauna was carried out on the size fractions $150-250 \mu \mathrm{m}$ and $>250 \mu \mathrm{m}$. Large foraminiferal samples were split using an Otto-microsplitter until they contained at least 200 specimens per size fraction. If less than 200 individuals were present, the total fraction was picked. The taxonomy used here follows Hemleben et al. (1989). The results are presented for both fractions combined (i.e. the $>150 \mu \mathrm{m}$ fraction). Flux data for planktic foraminifera are given in individuals per meter square per day (Ind. $\mathrm{m}^{-2} \mathrm{~d}^{-1}$ ) considering the sample split, sampling area of the sediment trap, and the duration of each collection period. Raw data are available as online supporting materials (Appendix A).

Table 1

Total mass flux, F/P ratio and foraminiferal test fluxes collected at $800 \mathrm{~m}$ water depth in the SE Bay of Biscay from June 2006 to July 2007.

\begin{tabular}{|c|c|c|c|c|c|c|c|c|c|}
\hline & Collection & Mass flux & F/P-ratio & F/P-ratio & PF tests $>150 \mu \mathrm{m}$ & G. bulloides & N. incompta & G. inflata & BF tests $>150 \mu \mathrm{m}$ \\
\hline Mid date & Time $(\mathrm{d})$ & {$\left[\mathrm{mg} \mathrm{m}^{-2} \mathrm{~d}^{-1}\right]$} & $\overline{\text { Measured }}$ & $\overline{\text { Calculated }}$ & [Ind. $\left.\mathrm{m}^{-2} \mathrm{~d}^{-1}\right]$ & [Ind. $\left.\mathrm{m}^{-2} \mathrm{~d}^{-1}\right]$ & $\overline{\left[\text { Ind. } \mathrm{m}^{-2} \mathrm{~d}^{-1}\right]}$ & [Ind. $\mathrm{m}^{-2} \mathrm{~d}^{-1}$ ] & [Ind. $\mathrm{m}^{-2} \mathrm{~d}^{-1}$ ] \\
\hline $6 / 28 / 2006$ & 12 & 77 & - & 0.6 & 1783 & 1121 & 415 & 51 & 0 \\
\hline $7 / 10 / 2006$ & 12 & 103 & 0.8 & 0.8 & 1135 & 616 & 280 & 62 & 0 \\
\hline $7 / 22 / 2006$ & 12 & 68 & - & 0.6 & 639 & 137 & 212 & 25 & 0 \\
\hline $8 / 3 / 2006$ & 12 & 102 & - & 0.8 & 644 & 135 & 324 & 27 & 0 \\
\hline $8 / 15 / 2006$ & 12 & 108 & 0.9 & 0.9 & 707 & 117 & 330 & 29 & 0 \\
\hline $8 / 27 / 2006$ & 12 & 41 & 0.3 & 0.3 & 166 & 23 & 74 & 11 & 0 \\
\hline $9 / 8 / 2006$ & 12 & 30 & 0.3 & 0.2 & 90 & 11 & 40 & 7 & 1 \\
\hline $9 / 20 / 2006$ & 12 & 35 & - & 0.3 & 112 & 15 & 51 & 5 & 0 \\
\hline $10 / 2 / 2006$ & 12 & 38 & 0.4 & 0.3 & 113 & 14 & 56 & 10 & 1 \\
\hline $10 / 14 / 2006$ & 12 & 38 & - & 0.3 & 85 & 14 & 38 & 6 & 1 \\
\hline $10 / 26 / 2006$ & 12 & 33 & 0.3 & 0.3 & 68 & 10 & 30 & 6 & 1 \\
\hline $11 / 7 / 2006$ & 12 & 19 & 0.3 & 0.2 & 41 & 7 & 18 & 3 & 2 \\
\hline $11 / 19 / 2006$ & 12 & 28 & 0.3 & 0.2 & 39 & 7 & 17 & 2 & 2 \\
\hline $12 / 1 / 2006$ & 12 & 63 & - & 0.5 & 90 & 18 & 35 & 10 & 3 \\
\hline $12 / 13 / 2006$ & 12 & 116 & 1.0 & 0.9 & 72 & 15 & 25 & 9 & 2 \\
\hline $12 / 25 / 2006$ & 12 & 65 & 0.6 & 0.5 & 67 & 11 & 23 & 14 & 3 \\
\hline $1 / 6 / 2007$ & 12 & 38 & 0.4 & 0.3 & 99 & 17 & 38 & 23 & 3 \\
\hline $1 / 18 / 2007$ & 12 & 54 & - & 0.4 & 82 & 13 & 33 & 19 & 2 \\
\hline $1 / 30 / 2007$ & 12 & 33 & 0.3 & 0.3 & 44 & 5 & 16 & 11 & 1 \\
\hline $2 / 11 / 2007$ & 12 & 84 & 0.8 & 0.7 & 44 & 5 & 17 & 9 & 3 \\
\hline $2 / 23 / 2007$ & 12 & 99 & 0.7 & 0.8 & 57 & 8 & 22 & 13 & 4 \\
\hline $3 / 7 / 2007$ & 12 & 113 & 0.7 & 0.9 & 54 & 12 & 19 & 6 & 6 \\
\hline $3 / 19 / 2007$ & 12 & 96 & 0.8 & 0.8 & 68 & 16 & 24 & 7 & 14 \\
\hline $3 / 31 / 2007$ & 12 & 67 & 0.5 & 0.5 & 50 & 11 & 15 & 8 & 16 \\
\hline- & (10) & - & - & - & - & - & - & - & - \\
\hline $4 / 18 / 2007$ & 5 & 150 & - & 1.2 & 551 & 170 & 156 & 47 & 2 \\
\hline $4 / 24 / 2007$ & 6 & 124 & 0.9 & 1.0 & 548 & 101 & 106 & 79 & 3 \\
\hline $4 / 30 / 2007$ & 6 & 98 & 0.7 & 0.8 & 311 & 68 & 65 & 48 & 8 \\
\hline $5 / 6 / 2007$ & 6 & 110 & - & 0.9 & 594 & 192 & 86 & 81 & 13 \\
\hline $5 / 12 / 2007$ & 6 & 367 & 2.9 & 3.0 & 563 & 168 & 139 & 62 & 32 \\
\hline $5 / 18 / 2007$ & 6 & 353 & 3.0 & 2.9 & 737 & 161 & 183 & 107 & 173 \\
\hline $5 / 24 / 2007$ & 6 & 107 & - & 0.9 & 264 & 60 & 58 & 39 & 53 \\
\hline $5 / 30 / 2007$ & 6 & 100 & 0.9 & 0.8 & 174 & 31 & 57 & 35 & 44 \\
\hline $6 / 8 / 2007$ & 12 & 40 & - & 0.3 & 78 & 18 & 21 & 14 & 23 \\
\hline $6 / 20 / 2007$ & 12 & 16 & 0.2 & 0.1 & 24 & 4 & 6 & 6 & 7 \\
\hline $7 / 2 / 2007$ & 12 & 18 & - & 0.1 & 12 & 2 & 3 & 3 & 6 \\
\hline $7 / 14 / 2007$ & 12 & 72 & - & 0.6 & 180 & 30 & 59 & 39 & 69 \\
\hline $7 / 26 / 2007$ & - & - & - & - & - & - & - & - & - \\
\hline
\end{tabular}


Table 2

Total mass flux, F/P ratio and foraminiferal test fluxes collected at $1700 \mathrm{~m}$ water depth in the SE Bay of Biscay from June 2006 to June 2008.

\begin{tabular}{|c|c|c|c|c|c|c|c|c|c|}
\hline & Collection & Mass flux & F/P-ratio & F/P-ratio & PF tests $>150 \mu \mathrm{m}$ & G. bulloides & N. incompta & G. inflata & BF tests $>150 \mu \mathrm{m}$ \\
\hline Mid date & Time (d) & $\overline{\left[\mathrm{mg} \mathrm{m}^{-2} \mathrm{~d}^{-1}\right]}$ & $\overline{\text { Measured }}$ & $\overline{\text { Calculated }}$ & [Ind. $\left.\mathrm{m}^{-2} \mathrm{~d}^{-1}\right]$ & $\overline{\left[\text { Ind. } \mathrm{m}^{-2} \mathrm{~d}^{-1}\right]}$ & $\overline{\left[\text { Ind. } \mathrm{m}^{-2} \mathrm{~d}^{-1}\right]}$ & {$\left[\right.$ [nd. $\left.\mathrm{m}^{-2} \mathrm{~d}^{-1}\right]$} & [Ind. $\mathrm{m}^{-2} \mathrm{~d}^{-1}$ ] \\
\hline $6 / 28 / 2006$ & 12 & 124 & - & 0.8 & 1082 & 581 & 360 & 40 & 0 \\
\hline $7 / 10 / 2006$ & 12 & 119 & 0.6 & 0.8 & 710 & 415 & 115 & 22 & 0 \\
\hline $7 / 22 / 2006$ & 12 & 170 & - & 1.1 & 1309 & 439 & 425 & 50 & 0 \\
\hline $8 / 3 / 2006$ & 12 & 190 & - & 1.2 & 861 & 180 & 519 & 19 & 0 \\
\hline $8 / 15 / 2006$ & 12 & 207 & 1.2 & 1.3 & 837 & 102 & 411 & 39 & 0 \\
\hline $8 / 27 / 2006$ & 12 & 167 & - & 1.1 & 348 & 56 & 158 & 30 & 0 \\
\hline $9 / 8 / 2006$ & 12 & 143 & 1.1 & 1.0 & 129 & 20 & 50 & 19 & 0 \\
\hline $9 / 20 / 2006$ & 12 & 131 & - & 0.9 & 66 & 9 & 25 & 7 & 0 \\
\hline $10 / 2 / 2006$ & 12 & 116 & 0.8 & 0.8 & 59 & 7 & 27 & 7 & 0 \\
\hline $10 / 14 / 2006$ & 12 & 79 & - & 0.5 & 52 & 9 & 22 & 6 & 0 \\
\hline $10 / 26 / 2006$ & 12 & 71 & 0.7 & 0.5 & 28 & 10 & 8 & 2 & 0 \\
\hline $11 / 7 / 2006$ & 12 & 84 & 0.8 & 0.6 & 30 & 10 & 6 & 1 & 0 \\
\hline $11 / 19 / 2006$ & 12 & 224 & 1.6 & 1.4 & 68 & 20 & 15 & 17 & 0 \\
\hline $12 / 1 / 2006$ & 12 & 517 & - & 2.7 & 212 & 38 & 65 & 64 & 0 \\
\hline $12 / 13 / 2006$ & 12 & 620 & 2.5 & 3.0 & 208 & 36 & 75 & 68 & 0 \\
\hline $12 / 25 / 2006$ & 12 & 44 & 0.4 & 0.3 & 105 & 12 & 39 & 42 & 0 \\
\hline $1 / 6 / 2007$ & 12 & 34 & 0.2 & 0.2 & 25 & 4 & 8 & 10 & 0 \\
\hline $1 / 18 / 2007$ & 12 & 221 & 1.1 & 1.4 & 75 & 12 & 29 & 21 & 0 \\
\hline $1 / 30 / 2007$ & 12 & 184 & - & 1.2 & 43 & 6 & 17 & 12 & 0 \\
\hline $2 / 11 / 2007$ & 12 & 62 & 0.4 & 0.4 & 10 & 1 & 5 & 2 & 0 \\
\hline $2 / 23 / 2007$ & 12 & 812 & 4.1 & 3.4 & 162 & 42 & 71 & 18 & 1 \\
\hline $3 / 7 / 2007$ & 12 & 407 & 2.0 & 2.3 & 346 & 63 & 148 & 31 & 2 \\
\hline $3 / 19 / 2007$ & 12 & 272 & 1.5 & 1.7 & 308 & 74 & 85 & 44 & 3 \\
\hline- & $(22)$ & - & - & - & - & - & - & - & - \\
\hline $4 / 18 / 2007$ & 5 & 128 & - & 0.9 & 516 & 142 & 245 & 86 & 0 \\
\hline $4 / 24 / 2007$ & 6 & 179 & 1.1 & 1.2 & 547 & 223 & 183 & 58 & 0 \\
\hline $4 / 30 / 2007$ & 6 & 177 & - & 1.2 & 247 & 85 & 97 & 19 & 0 \\
\hline $5 / 6 / 2007$ & 6 & 133 & - & 0.9 & 286 & 63 & 91 & 43 & 0 \\
\hline $5 / 12 / 2007$ & 6 & 150 & 1.0 & 1.0 & 343 & 61 & 80 & 47 & 0 \\
\hline $5 / 18 / 2007$ & 6 & 157 & - & 1.0 & 295 & 78 & 74 & 33 & 0 \\
\hline $5 / 24 / 2007$ & 6 & 213 & - & 1.4 & 430 & 202 & 83 & 27 & 0 \\
\hline $5 / 30 / 2007$ & 6 & 213 & 1.3 & 1.4 & 936 & 440 & 143 & 175 & 0 \\
\hline $6 / 8 / 2007$ & 12 & 235 & - & 1.5 & 363 & 143 & 43 & 19 & 0 \\
\hline $6 / 20 / 2007$ & 12 & 260 & 1.7 & 1.6 & 241 & 63 & 83 & 26 & 0 \\
\hline $7 / 2 / 2007$ & 12 & 272 & - & 1.7 & 279 & 29 & 140 & 38 & 0 \\
\hline $7 / 14 / 2007$ & 12 & 307 & 1.9 & 1.9 & 173 & 8 & 91 & 39 & 0 \\
\hline $7 / 26 / 2007$ & 12 & 154 & - & 1.0 & 318 & 28 & 153 & 71 & 1 \\
\hline $8 / 4 / 2007$ & 6 & 214 & 1.4 & 1.4 & 60 & 10 & 21 & 14 & 0 \\
\hline $8 / 10 / 2007$ & 6 & 118 & - & 0.8 & 17 & 2 & 6 & 4 & 0 \\
\hline $8 / 16 / 2007$ & 6 & 154 & - & 1.0 & 37 & 3 & 16 & 5 & 0 \\
\hline $8 / 25 / 2007$ & 12 & 84 & - & 0.6 & 10 & 1 & 3 & 1 & 0 \\
\hline $9 / 6 / 2007$ & 12 & 98 & - & 0.7 & 31 & 5 & 7 & 6 & 0 \\
\hline $9 / 18 / 2007$ & 12 & 50 & 0.4 & 0.4 & 9 & 0 & 3 & 1 & 0 \\
\hline $9 / 30 / 2007$ & 12 & 77 & 0.6 & 0.5 & 5 & 0 & 1 & 1 & 0 \\
\hline $10 / 12 / 2007$ & 12 & 142 & 0.9 & 1.0 & 9 & 2 & 0 & 1 & 0 \\
\hline $10 / 24 / 2007$ & 12 & 166 & 1.4 & 1.1 & 20 & 1 & 3 & 3 & 0 \\
\hline $11 / 5 / 2007$ & 12 & 102 & 0.8 & 0.7 & 7 & 1 & 1 & 1 & 0 \\
\hline $11 / 17 / 2007$ & 12 & 112 & 0.8 & 0.8 & 6 & 2 & 1 & 1 & 0 \\
\hline $12 / 1 / 2007$ & 12 & 100 & - & 0.7 & 25 & 2 & 2 & 8 & 0 \\
\hline $12 / 13 / 2007$ & 12 & 298 & 1.8 & 1.8 & 219 & 26 & 47 & 54 & 0 \\
\hline $12 / 25 / 2007$ & 12 & 150 & - & 1.0 & 183 & 29 & 39 & 52 & 0 \\
\hline $1 / 6 / 2008$ & 12 & 75 & - & 0.5 & 92 & 14 & 21 & 41 & 0 \\
\hline $1 / 17 / 2008$ & 10 & 108 & 0.9 & 0.7 & 129 & 9 & 32 & 61 & 0 \\
\hline $1 / 27 / 2008$ & 10 & 99 & - & 0.7 & 84 & 5 & 21 & 44 & 0 \\
\hline $2 / 6 / 2008$ & 10 & 341 & - & 2.0 & 332 & 22 & 152 & 120 & 1 \\
\hline $2 / 16 / 2008$ & 10 & 460 & 2.4 & 2.5 & 190 & 19 & 78 & 63 & 0 \\
\hline $2 / 26 / 2008$ & 10 & 245 & - & 1.5 & 179 & 26 & 69 & 61 & 0 \\
\hline $3 / 7 / 2008$ & 10 & 316 & 2.3 & 1.9 & 409 & 148 & 133 & 84 & 0 \\
\hline $3 / 17 / 2008$ & 10 & 306 & - & 1.9 & 784 & 336 & 195 & 122 & 0 \\
\hline $3 / 27 / 2008$ & 10 & 212 & - & 1.4 & 458 & 126 & 136 & 83 & 0 \\
\hline $4 / 6 / 2008$ & 10 & 158 & - & 1.1 & 674 & 94 & 298 & 248 & 0 \\
\hline $4 / 14 / 2008$ & 7 & 136 & 0.9 & 0.9 & 2304 & 751 & 939 & 445 & 0 \\
\hline $4 / 21 / 2008$ & 7 & 379 & - & 2.2 & 2009 & 882 & 482 & 266 & 0 \\
\hline $4 / 28 / 2008$ & 7 & 915 & 2.8 & 3.5 & 1033 & 327 & 299 & 203 & 0 \\
\hline $5 / 5 / 2008$ & 7 & 307 & - & 1.9 & 1907 & 586 & 251 & 194 & 2 \\
\hline $5 / 12 / 2008$ & 7 & 188 & - & 1.2 & 1247 & 499 & 226 & 93 & 0 \\
\hline $5 / 19 / 2008$ & 7 & 92 & - & 0.6 & 1413 & 509 & 178 & 174 & 0 \\
\hline $5 / 26 / 2008$ & 7 & 67 & 0.4 & 0.5 & 595 & 208 & 102 & 55 & 0 \\
\hline $6 / 2 / 2008$ & 7 & 39 & - & 0.3 & 315 & 100 & 59 & 33 & 0 \\
\hline $6 / 9 / 2008$ & 7 & 36 & 0.1 & 0.3 & 210 & 65 & 40 & 27 & 0 \\
\hline $6 / 16 / 2008$ & 7 & 55 & - & 0.4 & 245 & 76 & 53 & 21 & 0 \\
\hline $6 / 23 / 2008$ & 7 & 139 & 0.7 & 0.9 & 491 & 138 & 87 & 49 & 1 \\
\hline
\end{tabular}




\subsection{Analyses of ${ }^{210} \mathrm{~Pb}$ and ${ }^{226} \mathrm{Ra}$ isotopes}

Half of each original sample was used for mass flux determination. Particles were concentrated by centrifugation, rinsed with deionised water to remove salts, lyophilized, and weighted to estimate particle flux. Since the dry weight of all samples was $>100 \mathrm{mg}$, we are confident about the precision of our mass flux data. Average mass fluxes discussed in the paper are time-weighted means, i.e., means of the mass flux (in $\mathrm{mg} \mathrm{m}^{-2} \mathrm{~d}^{-1}$ ) presented in Tables 1 and 2, multiplied by the number of collection days.

Measurements of ${ }^{210} \mathrm{~Pb}$ and ${ }^{226} \mathrm{Ra}$ activity were completed using a Canberra (Ge volume $280 \mathrm{~cm}^{3}$ ) low background, high-efficiency, well-shaped-detector (Schmidt et al., 2009). ${ }^{210} \mathrm{~Pb}$ was determined by its specific gamma ray signal at $46.5 \mathrm{keV}$, and ${ }^{226} \mathrm{Ra}$ by the rays of its decay products, at 295 and $352 \mathrm{keV}$ for ${ }^{214} \mathrm{~Pb}$, and $609 \mathrm{keV}$ for ${ }^{214} \mathrm{Bi}$. IAEA standards used for the calibration of the $\gamma$ detector were RGU-1 and RGTh-1. Excess ${ }^{210} \mathrm{~Pb}$ in settling particles, i.e., ${ }^{210} \mathrm{~Pb}_{\mathrm{xs}}$ scavenged from seawater, was calculated by subtracting the activity supported by its parent isotope, ${ }^{226} \mathrm{Ra}$, from the total ${ }^{210} \mathrm{~Pb}$ activity in particles. In all trap samples, ${ }^{210} \mathrm{~Pb}_{\mathrm{xs}}$ represents $>99 \%$ of the total ${ }^{210} \mathrm{~Pb}$.

\subsection{Calculation of F/P ratios}

The determination of ${ }^{210} \mathrm{~Pb}$ radionuclide activity in settling particles collected in sediment traps provides information to discriminate the origin of the trapped matter. In the open ocean, the predicted flux $(\mathrm{P})$ is related to two sources of ${ }^{210} \mathrm{~Pb}$ : (1) the atmospheric fallout of ${ }^{210} \mathrm{~Pb}$ to surface waters, and (2) production of ${ }^{210} \mathrm{~Pb}$ in the water column from decay of ${ }^{226} \mathrm{Ra}$ (Cochran et al., 1990; Schmidt et al., 2009). The budget of ${ }^{210} \mathrm{~Pb}$ at Station $\mathrm{WH}$ was used to assess the rate of downward versus lateral transport of particles by comparing the trapped ${ }^{210} \mathrm{~Pb}_{\mathrm{xs}}$ flux $(\mathrm{F})$ and the predicted ${ }^{210} \mathrm{~Pb}$ flux $(\mathrm{P})$ using the focusing ratio (F/P) (Figs. 2 and 3; Tables 1 and 2). Correlation curves have been calculated between measured mass fluxes and measured $\mathrm{F} / \mathrm{P}$ ratio to obtain the calculated $\mathrm{F} /$ P ratios (Figs. 2 and 3; Tables 1 and 2; see also Fig. 4 in Schmidt et al., 2009). Average $\mathrm{F} / \mathrm{P}$ ratios discussed in the paper are time-weighted and flux-weighted mean ratios, i.e., means of calculated F/P ratio multiplied by mass fluxes (in $\mathrm{mg} \mathrm{m}^{-2} \mathrm{~d}^{-1}$ ) presented in Tables 1 and 2, multiplied by the numbers of collection days. Values of $\mathrm{F} / \mathrm{P}>1$ suggest either sediment focusing or lateral input of ${ }^{210} \mathrm{~Pb}$ to the considered site, and values of $\mathrm{F} / \mathrm{P}<1$ indicate predominantly vertical sediment flux (Muhammad et al., 2008).

\section{Results}

\subsection{Total mass flux}

Over the duration of trap deployment, total mass flux varied between 16 and $367 \mathrm{mg} \mathrm{m}^{-2} \mathrm{~d}^{-1}$ at $800 \mathrm{~m}$, and between 34 and $915 \mathrm{mg} \mathrm{m}^{-2} \mathrm{~d}^{-1}$ at $1700 \mathrm{~m}$ (Figs. 2 and 3; Tables 1 and 2). During the first year of deployment (June 2006 to June 2007), the average flux was $212 \mathrm{mg} \mathrm{m}^{-2} \mathrm{~d}^{-1}$ at $1700 \mathrm{~m}$, and $77 \mathrm{mg} \mathrm{m}^{-2} \mathrm{~d}^{-1}$ at $800 \mathrm{~m}$ depth.

Mass flux exhibited large changes that rapidly occurred over short time-periods ( $<2$ weeks). Variability in mass flux to the deeper trap was slightly higher than to the shallower trap. The amplitude of flux variations (flux $x_{\max } /$ flux $_{\min }$ ) increased from a factor of 23 in the $800-\mathrm{m}$ trap to 27 in the $1700-m$ trap. At $800 \mathrm{~m}$ water depth, a single remarkable mass flux event of $360 \mathrm{mg} \mathrm{m}^{-2} \mathrm{~d}^{-1}$ occurred during 2 weeks in mid May 2007 (Fig. 2; Table 1). At $1700 \mathrm{~m}$ water depth, mass flux events were intense in winter and early spring (Fig. 3; Table 2). The deep trap received large and abrupt mass dumps in winter 2006/2007, with values up to $620 \mathrm{mg} \mathrm{m}^{-2} \mathrm{~d}^{-1}$ in December 2006, $812 \mathrm{mg} \mathrm{m}^{-2} \mathrm{~d}^{-1}$ in February 2007, and a maximum of $915 \mathrm{mg} \mathrm{m}^{-2} \mathrm{~d}^{-1}$ in April 2008. Significant mass flux peaks of up to $350-450 \mathrm{mg} \mathrm{m}^{-2} \mathrm{~d}^{-1}$ were also recorded in
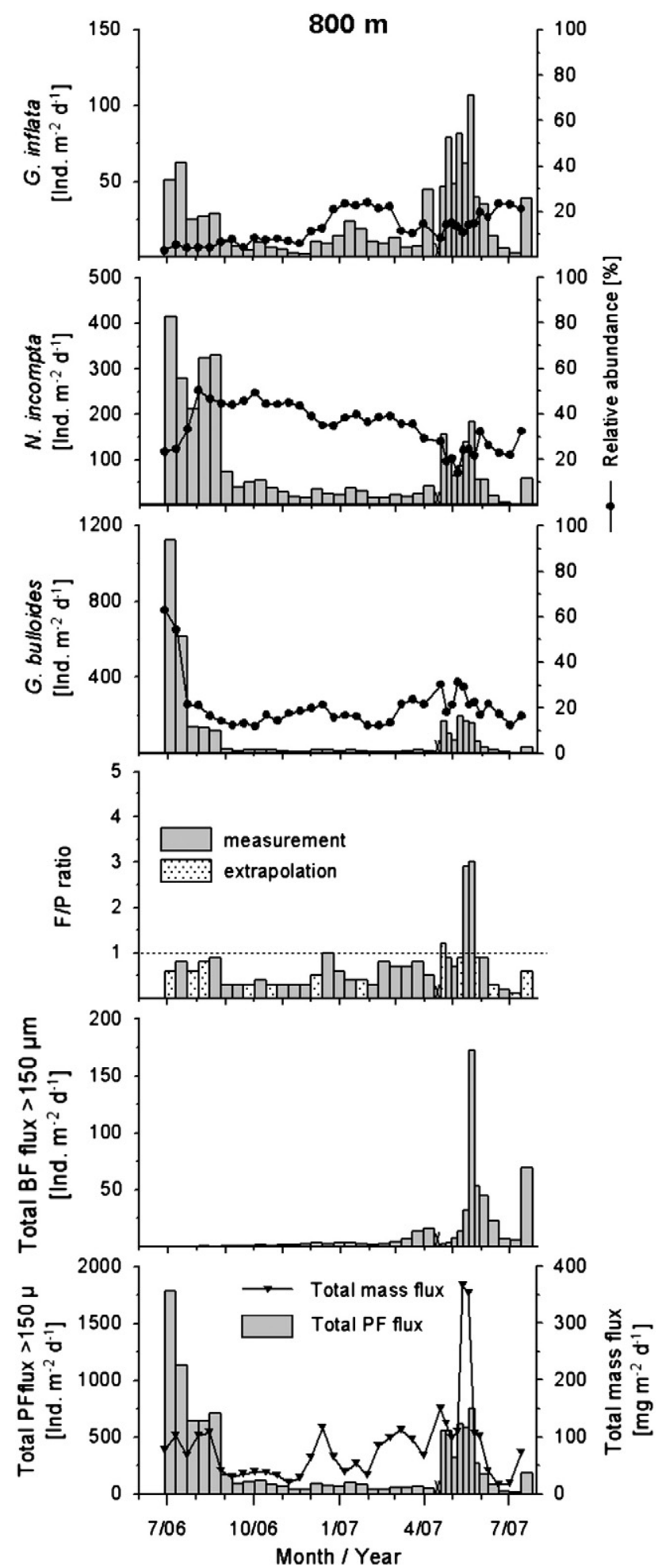

Fig. 2. Total foraminiferal test fluxes, total mass flux and $\mathrm{F} / \mathrm{P}$ ratio recorded at $800 \mathrm{~m}$ from June 2006 to July 2007. Specific fluxes of the most abundant PF species are given in absolute and relative abundances (with maximum binomial standard error of $9.6 \%$ for G. bulloides, $8.6 \%$ for N. incompta and $8.5 \%$ for G. inflata, and mean binomial standard error of $3.6 \%, 3.2 \%$ and $4.4 \%$ respectively). Please note the differences in scales for the PF test flux. F/P values $>1$ indicate lateral particle input (dashed line). Extrapolated $\mathrm{F} / \mathrm{P}$ ratios are marked by dotted bars. Extrapolation of $\mathrm{F} / \mathrm{P}$ ratios follows $y=0,0081 x\left(r^{2}=0.98\right)$, with $x$ being measured mass flux (Table 1$)$. On the $x$-axis, the beginnings of months are given. $\mathrm{X}$ indicates sampling gap.

winter 2007/08. Mass flux was low and even during the summer with some events of about $300 \mathrm{mg} \mathrm{m}^{-2} \mathrm{~d}^{-1}$ in 2007. During the fall, enhanced flux events were rare. 

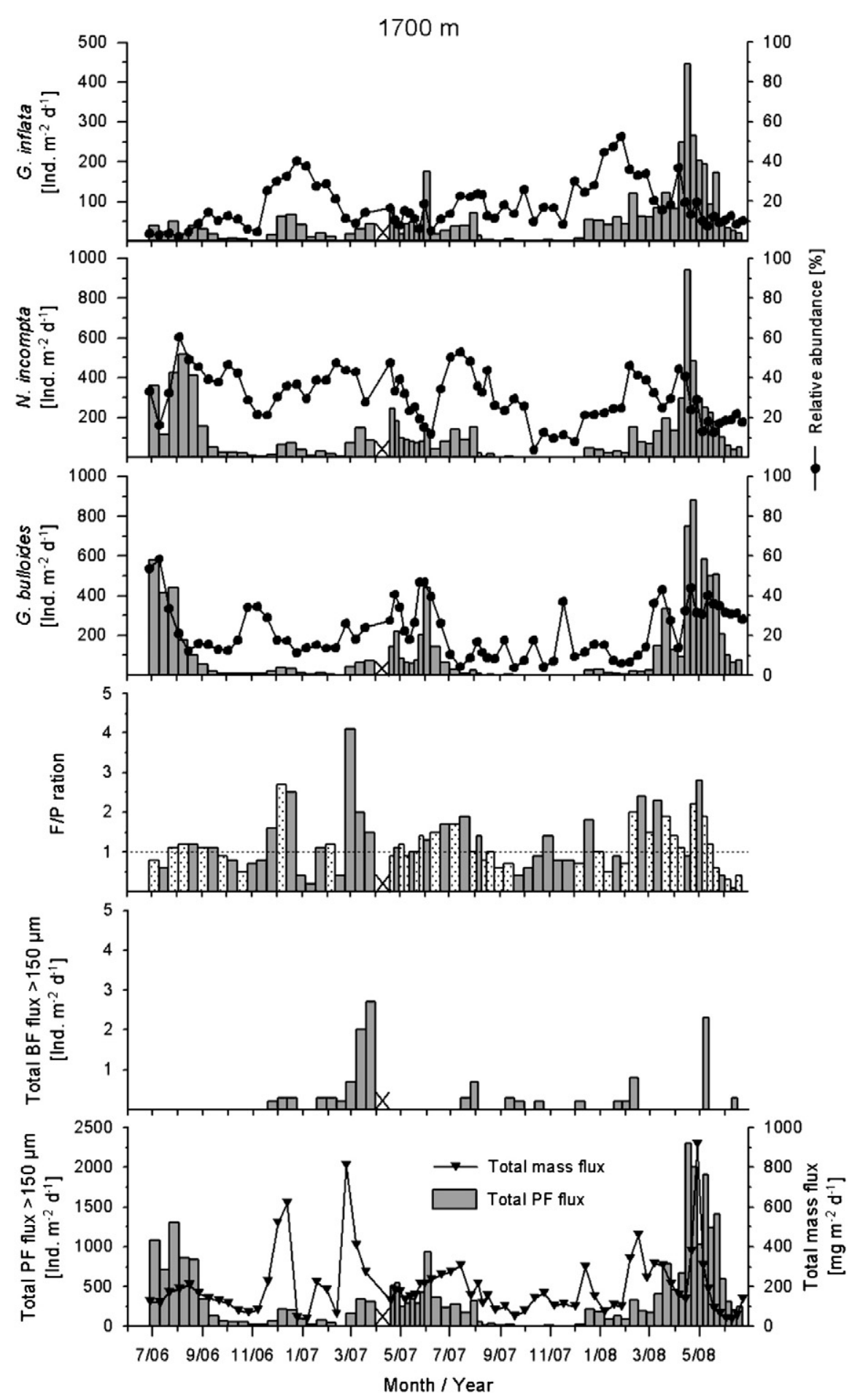

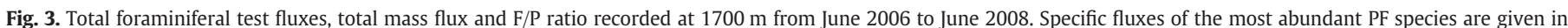

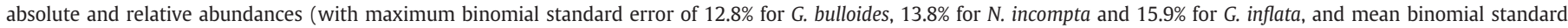

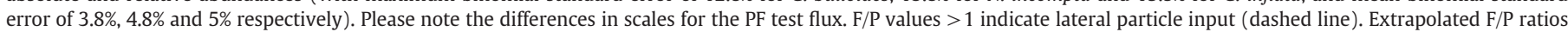

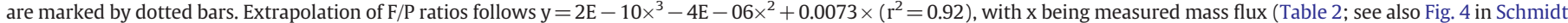
et al., 2009). On the $\mathrm{X}$-axis, the beginnings of months are given. $\mathrm{X}$ indicates sampling gap.

\subsection{Downward flux and lateral sediment flux}

Trapped ${ }^{210} \mathrm{~Pb}$ fluxes (F) increased with depth from 3-60 dpm m $\mathrm{m}^{-2} \mathrm{~d}^{-1}$ at $800 \mathrm{~m}$ to $4-110 \mathrm{dpm} \mathrm{m}^{-2} \mathrm{~d}^{-1}$ at $1700 \mathrm{~m}$, showing a positive linear correlation with the mass flux (Fig. 5 in Schmidt et al., 2009). ${ }^{210} \mathrm{~Pb}$ specific activities of trapped particles were highest at depth, similarly to the adjacent Cap-Ferret canyon (Radakovitch and Heussner, 1999). At $1700 \mathrm{~m}, 300 \mathrm{~m}$ above bottom, the mean settling ${ }^{210} \mathrm{~Pb}$ flux agreed well with that recorded from the surface sediment, indicating that particulate fluxes recorded over the observed time-period are representative of longer-term accumulation periods (Schmidt et al., 2009).

Mean F/P ratios of trapped particles increased with depth from 1 at $800 \mathrm{~m}$ to 1.8 at $1700 \mathrm{~m}$ depth, indicating an increase of the contribution of lateral over downward flux with depth. At both water depths, however, F/P ratios exhibited large variations between 0.2 

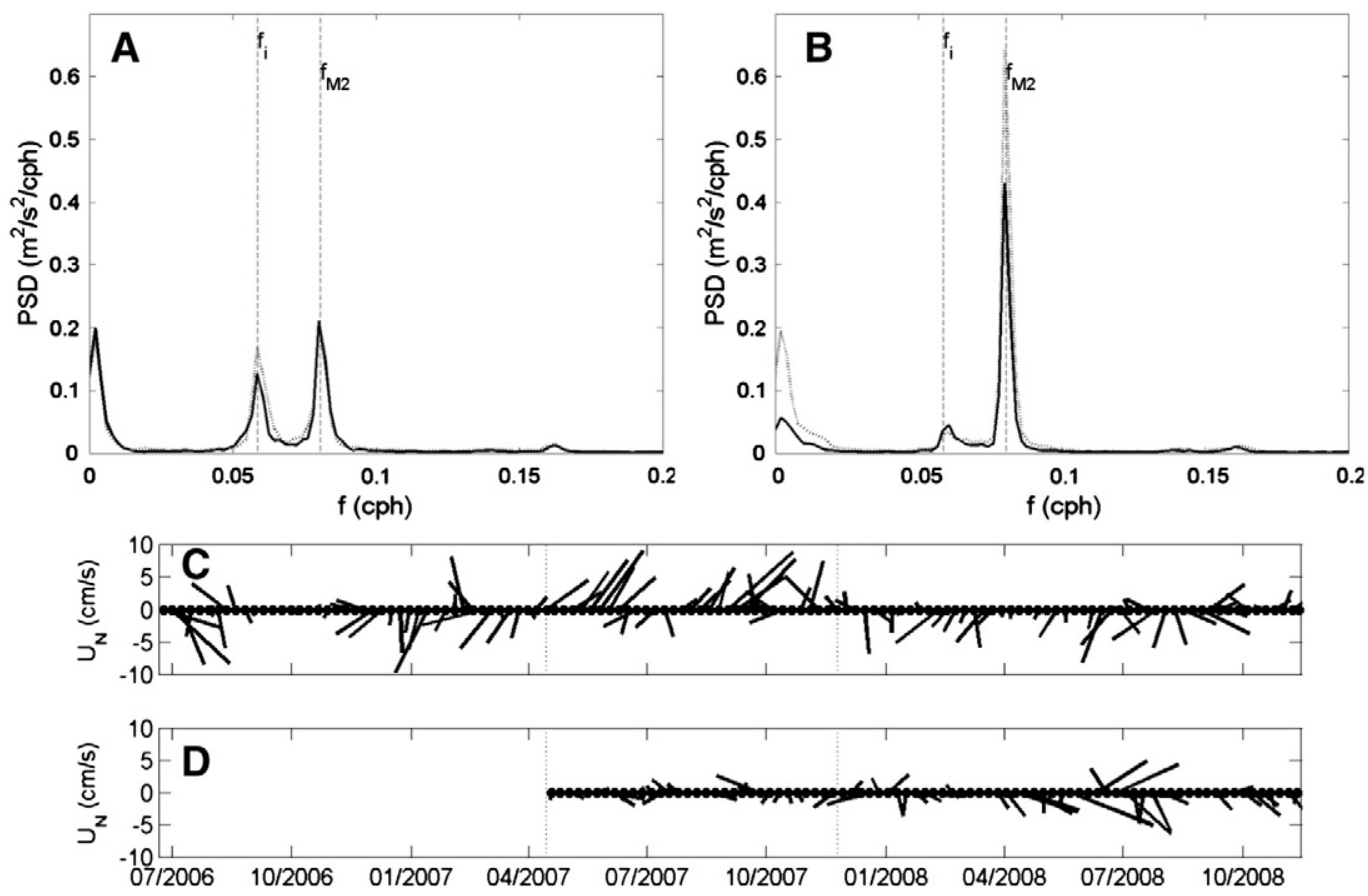

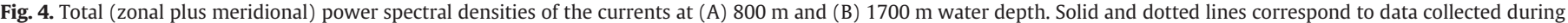

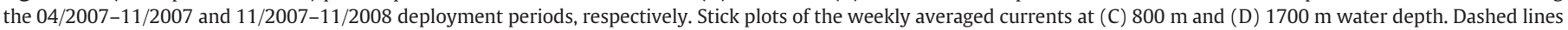
mark the mooring recovery / redeployment dates.

and 3 at $800 \mathrm{~m}$, and between 0.1 and 4.1 at $1700 \mathrm{~m}$ depth (Figs. 2 and 3; Tables 1 and 2). Sporadic increases in $\mathrm{F} / \mathrm{P}$ ratios are ascribed to temporary high lateral transport of suspended particles (Schmidt et al., 2009). In general, F/P ratio variations match well the total mass flux variations at both water depths. At $800 \mathrm{~m}$, a positive linear correlation between $\mathrm{F} / \mathrm{P}$ ratios and mass flux follows $\mathrm{y}=0.00081 \mathrm{x}\left(\mathrm{r}^{2}=0.98\right)$, with $\mathrm{x}$ being measured mass fluxes. At $1700 \mathrm{~m}$, a positive polynomial correlation between $\mathrm{F} / \mathrm{P}$ ratios and mass flux follows $\mathrm{y}=2 \mathrm{E}-10 \mathrm{x}^{3}$ $4 \mathrm{E}-06 \mathrm{x}^{2}+0.0073 \mathrm{x}\left(\mathrm{r}^{2}=0.92\right)$, with $\mathrm{x}$ being measured mass fluxes.

Time-series of total mass flux and of $\mathrm{F} / \mathrm{P}$ ratios indicate the occurrence of lateral input and drastic changes in the relative contribution of lateral and vertical input to the particulate flux throughout the

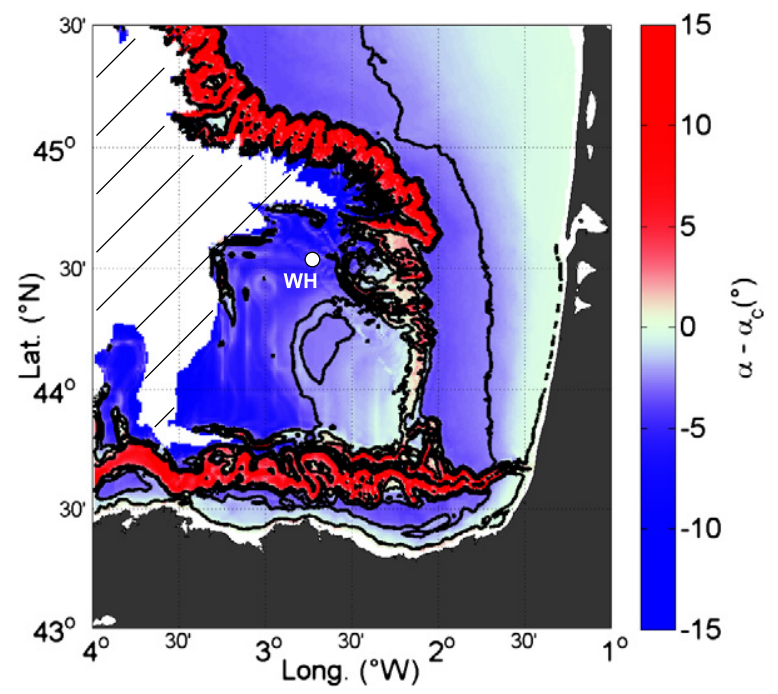

Fig. 5. Map of the SE Bay of Biscay, showing the spatial distribution of differences between the slope of the sea floor $(\alpha)$ and the direction of tidal energy rays $\left(\alpha_{c}\right)$ recorded by SHOM (Service Hydrographique et Océanographique de la Marine, France). A colour version of this figure is available online. year. These lateral input events showed a marked temporal variability resulting from a succession of more or less strong advection events. They were not synchronous at $800 \mathrm{~m}$ and $1700 \mathrm{~m}$ and mainly affected the deeper trap, implying that the mass-flux events were decoupled.

\subsection{Current meter data}

The power spectral densities computed from the current data at both the $800-\mathrm{m}$ and $1700-\mathrm{m}$ trap levels (Fig. $4 \mathrm{a}$ and b) show the total current variance at the deployment site to be due to three different kinds of processes corresponding to spectral content in the tidal ( $\mathrm{f} \geq \mathrm{f}_{\mathrm{M} 2}$, $\mathrm{T} \leq 12 \mathrm{~h})$, wind-forced inertial $\left(\mathrm{f}=\mathrm{f}_{\mathrm{i}}, \mathrm{T} \sim 17 \mathrm{~h}\right)$, and mesoscale-forced subtidal ( $\mathrm{f} \leq 0.025$ cycles/h, $\mathrm{T}>40 \mathrm{~h}$ ) frequency bands. Processes with a period shorter than one day (tide- and wind-forced currents) have an influence on extreme current characteristics (peak current velocity) and may affect the collection efficiency of the traps, while longer-period currents (mesoscale-forced circulation like eddies) influence the longrange lateral advection of suspended material.

A peak at the $M 2$ tide frequency ( $f_{M 2}$, Fig. $4 a$ and $b$ ) is conspicuous at both 800 and $1700 \mathrm{~m}$ depth. The height of the tidal signal was larger at $1700 \mathrm{~m}$ than at $800 \mathrm{~m}$. A significant increase in the energy density at the low-frequency end $(\mathrm{f}<0.025 \mathrm{cph}, \mathrm{T}>40 \mathrm{~h}$ ) indicates that local mesoscale circulation was stronger at $800 \mathrm{~m}$ than at $1700 \mathrm{~m}$ water depth (Fig. 4a and b).

Averaged current characteristics (zonal plus meridional components) and variance of the total current signal between the different frequency bands are presented in Table 3 . At $800 \mathrm{~m}$, the current variability was mainly dominated by long-period mesoscale processes, with winddriven and tidal variances of smaller amplitudes. At $1700 \mathrm{~m}$, the inertial oscillation contribution can be considered rather weak with respect to the comparatively large tidal and mesoscale contributions.

Weekly averaged current direction and intensity were analyzed for their temporal development (Fig. $4 \mathrm{c}$ and $\mathrm{d}$ ). The averaging procedure tends to filter out the inertial and tidal components in stick plots (Fig. 4c and d). At $800 \mathrm{~m}$ depth, currents of about $10 \mathrm{~cm} \mathrm{~s}^{-1}$ turned either anti-cyclonic (e.g. July 2006) or cyclonic (e.g. January 2007) in alternation with calm periods (October 2006). A four month period 
Table 3

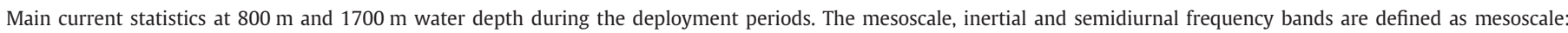
f $<0.025 \mathrm{cph}, \mathrm{T}>40 \mathrm{~h}$, inertial: $0.025 \mathrm{cph}<\mathrm{f}<0.07 \mathrm{cph}, 40 \mathrm{~h}<\mathrm{T}<14.3 \mathrm{~h}$, semidiurnal: $0.07 \mathrm{cph}<\mathrm{f}<0.25 \mathrm{cph}, 4.0 \mathrm{~h}<\mathrm{T}<14.3 \mathrm{~h}$.

\begin{tabular}{|c|c|c|c|c|c|c|c|c|}
\hline \multirow[t]{2}{*}{ Time Period } & \multirow[t]{2}{*}{ Water Depth (m) } & \multicolumn{2}{|c|}{ Mean current $\left(\mathrm{cm} \mathrm{s}^{-1}\right)$} & \multicolumn{4}{|c|}{ Current variances $\left(\mathrm{cm}^{2} \mathrm{~s}^{-2}\right)$} & \multirow[t]{2}{*}{ Proba. $U>15 \mathrm{~cm} . \mathrm{s}^{-1}$} \\
\hline & & Eastward & Northward & Total & Mesoscale & Inertial & Tidal & \\
\hline $2006 / 06-2007 / 04$ & 800 & -0.68 & -1.54 & 50.8 & 31.6 & 9.4 & 9.8 & $3.1 \%$ \\
\hline 2007/04-2007/11 & 800 & 1.61 & 2.87 & 71.5 & 46.4 & 9.3 & 15.9 & $7.3 \%$ \\
\hline $2007 / 11-2008 / 11$ & 800 & -0.38 & -1.26 & 60.6 & 29.0 & 12.3 & 19.2 & $2.4 \%$ \\
\hline $2006 / 06-2007 / 04$ & 1700 & - & - & - & - & - & - & \\
\hline $2007 / 04-2007 / 11$ & 1700 & 0.24 & -0.18 & 38.9 & 14.5 & 3.8 & 20.6 & $0.4 \%$ \\
\hline $2007 / 11-2008 / 11$ & 1700 & 2.30 & -1.17 & 74.6 & 37.1 & 4.4 & 33.1 & $6.7 \%$ \\
\hline
\end{tabular}

of strong north-easterly currents (up to $15 \mathrm{~cm} \mathrm{~s}^{-1}$ ) started in May 2007 (Fig. 4c). At $1700 \mathrm{~m}$ depth, long periods of rather sluggish currents alternated with periods of weak anticyclonic or cyclonic currents. From early April 2008, easterly currents of $5-10 \mathrm{~cm} \mathrm{~s}^{-1}$ were deflected either northward or southward (Fig. 4d). The mesoscale signal was well marked at both depths by long-period rotating currents, and enhanced the possible contribution of horizontal advection processes to the total signal.

In order to assess the influence of hydrodynamic conditions on the trap collection efficiency we have calculated the probability of the current modulus at the two trap levels to be in excess of $15 \mathrm{~cm} \mathrm{~s}^{-1}$ (Table 3). The worst-case figure of $7.3 \%$ of a record with currents above $15 \mathrm{~cm} / \mathrm{s}$ shows that our traps experienced relatively weak hydrodynamic bias (cf. Heussner et al., 1999). The mixed (tidal / mesoscale) character of the currents in the area implies that relatively high velocities occurred over periods when a significant mesoscale current merged with the tidal current. Hydrodynamic bias might then be suspected.

In general, currents were weaker at $1700 \mathrm{~m}$ than at $800 \mathrm{~m}$ water depth, and current directions at the two depths were not related in a systematic way. Mesoscale current activity occurred over periods of two to four months and was more intense at $800 \mathrm{~m}$ than at $1700 \mathrm{~m}$.

\subsection{Planktic foraminiferal test flux}

From June 2006 to June 2008, total planktic foraminiferal (PF) test flux $>150 \mu \mathrm{m}$ ranged between 10 and 1780 Ind. $\mathrm{m}^{-2} \mathrm{~d}^{-1}$ (an average of $\sim 270$ Ind. $\mathrm{m}^{-2} \mathrm{~d}^{-1}$ ) at $800 \mathrm{~m}$ depth and between 5 and 2300 Ind. $\mathrm{m}^{-2} \mathrm{~d}^{-1}$ (av. 340 Ind. $\mathrm{m}^{-2} \mathrm{~d}^{-1}$ ) at $1700 \mathrm{~m}$ depth (Figs. 2 and 3; Tables 1 and 2). During the first year of sampling (June 2006 to June 2007), the average PF flux at $1700 \mathrm{~m}$ was $~ 330$ Ind. $\mathrm{m}^{-2} \mathrm{~d}^{-1}$, showing the same order of magnitude as the flux $\left(\sim 360\right.$ Ind. $\left.\mathrm{m}^{-2} \mathrm{~d}^{-1}\right)$ during the second year of sampling (June 2007 to June 2008). Unfortunately, no data exist for the 800-m trap for the second year.

At both $800 \mathrm{~m}$ and $1700 \mathrm{~m}$ depth, PF fluxes showed a clear seasonality with highest fluxes during spring and early summer, and low fluxes during fall and winter (Figs. 2 and 3). In general, variability in PF flux was higher at the deeper trap $\left(\right.$ flux $_{\max } /$ flux $\left._{\min }=512\right)$ than at the shallower trap $\left(\right.$ flux $_{\max } /$ flux $_{\min }=153$ ), with sporadic peaks of enhanced PF flux in winter (Fig. 3). During the two year sampling period, variability in the intensity and in the timing of flux events was recorded at both $800-\mathrm{m}$ and $1700-\mathrm{m}$ traps. At $800 \mathrm{~m}$, PF flux was considerably higher during summer 2006 than 2007, and was not correlated to the total mass flux (Fig. 2). Enhanced PF fluxes at the 1700-m trap occurred during the spring to early summer of 2007 and 2008, and were slightly offset and considerably different in quantities. The highest total PF flux of up to 2300 Ind. $\mathrm{m}^{-2} \mathrm{~d}^{-1} \mathrm{oc}-$ curred between April and June 2008, whereas the peak flux in spring 2007 was less than 1000 Ind. $\mathrm{m}^{-2} \mathrm{~d}^{-1}$ (Fig. 3). In addition, shortterm increases in total PF flux at the 1700-m trap were observed in December 2006 and 2007 (>200 Ind. $\mathrm{m}^{-2} \mathrm{~d}^{-1}$ ), and were matched by peaks in the total mass flux.
Among 16 planktic foraminiferal species identified, Globigerina bulloides, Neogloboquadrina incompta, and Globorotalia inflata were most abundant, forming about $75 \%$ of the total PF fauna at both depths. The general temporal pattern of fluxes of these three species were correlated to the total PF flux, with maximum values in spring and early summer, and low values in fall and winter (Figs. 2 and 3). In addition, individual species fluxes at $1700 \mathrm{~m}$ during winter and spring of 2006/2007 showed sporadic increases. The increases were correlated to peaks in the total mass flux and total PF flux (Fig. 3). At times of high PF flux, G. bulloides and N. incompta accounted for up to $70 \%$ of the total PF flux, while the relative contribution of $G$. inflata was $<20 \%$. Post-spring conditions were marked by a decline in the relative abundance of $G$. bulloides, and $N$. incompta became dominant for the rest of the year. An exception was the winter/spring season 2007/2008, when a significant decrease in the relative abundance of $N$. incompta was observed. Winter was characterized by maximum relative abundances of $G$. inflata.

\subsection{Benthic foraminiferal test flux}

At the 800-m trap, an input of benthic foraminiferal (BF) tests $>150 \mu \mathrm{m}$ was recorded almost throughout the whole sampling period, showing average values of 10 Ind. $\mathrm{m}^{-2} \mathrm{~d}^{-1}$ (Fig. 2). The highest BF flux of up to 170 Ind. $\mathrm{m}^{-2} \mathrm{~d}^{-1}$ occurred in May 2007, and correlated to maxima in total mass flux, F/P ratios, and PF flux. At the 1700-m trap, the BF flux $>150 \mu \mathrm{m}$ was considerably lower (max. 3 Ind. $\mathrm{m}^{-2} \mathrm{~d}^{-1}$, av. 0.2 Ind. $\mathrm{m}^{-2} \mathrm{~d}^{-1}$ ) than at the 800-m trap (Fig. 3). Maximum BF flux occurred in winter and spring together with enhanced total mass flux and high F/P ratios (e.g. March 2007). In total, 22 benthic foraminiferal species were identified. The most frequent species were Cassidulina crassa, Eggerella scabra, Textularia sagittula, and Adercotryma glomerata.

\section{Discussion}

PF test flux in the hemipelagic Bay of Biscay at $44^{\circ} \mathrm{N}$ was of the same order of magnitude as flux reported from a hemipelagic site in the subtropical northeast Atlantic at $29^{\circ} \mathrm{N}$ (Abrantes et al., 2002; Canary Islands) and other tropical to temperate ocean basins (Table 4). Differences between fluxes recorded from different regions may partly be due to methodology (analyzed test size, depth of trap, sampling time interval) (Table 4). Both the Bay of Biscay and the Canary Basin are characterized by oligotrophic to mesotrophic conditions in the surface waters, as reflected by chlorophyll- $a$ concentrations (Bay of Biscay $0.2-2 \mathrm{mg} \mathrm{m}^{-3}$, versus Canary Basin $0.05-2 \mathrm{mg} \mathrm{m}^{-3}$ ) obtained during the trap experiments (Table 4; Abrantes et al., 2002). In comparison to the Bay of Biscay, PF fluxes were 2 to 10 times higher in hemipelagic regions influenced by pronounced seasonal upwelling, such as the Panama Basin (Thunell et al., 1983), the Pacific Ocean off Peru (Marchant et al., 1998), the California borderland (Thunell and Sautter, 1992), and the Indian Ocean off Indonesia (Mohtadi et al., 2009). Considerably higher test flux was also reported from the adjacent northeast Atlantic (Table 4; Schiebel, 2002). 
In comparison to the open northeast Atlantic Ocean (Abrantes et al., 2002: Canary Islands open ocean site), PF fluxes in the inner Bay of Biscay were slightly higher, which could be due to higher and more frequent nutrient supply to surface waters, for example, caused by river runoff (Table 4 ). Similar values were observed at the Walvis Ridge in the transitional south-eastern Atlantic at $27^{\circ} \mathrm{S}$ (Lončarić et al., 2007). Both areas off the Canary Islands and Walvis Ridge are marked by predominately oligotrophic conditions, although they are close to major upwelling areas off the West-African coast. In addition, interannual and inter-seasonal data reveal pronounced temporal variation of fluxes (e.g. Storz et al., 2009; Thunell and Honjo, 1981). Taking into consideration the methodological problems and differences between studies, as well as regional variability (e.g. Honjo and Manganini, 1993), our data are comparable to those reported earlier (Table 4), having similar average fluxes and seasonal variations (Figs. 2 and 3).

Mass flux including PF test flux exhibited large changes during the sampling period from June 2006 to June 2008 at Station WH. Fluxes of

${ }^{210} \mathrm{~Pb}$ increased with depth and exhibited temporal variations essentially matching variations in total mass flux as also reported for marginal environments by Biscaye et al. (1994) and Radakovitch and Heussner (1999).

However, time-series of sediment flux and of $\mathrm{F} / \mathrm{P}$ ratios indicate the occurrence of mass-flux events. Such events have been related to episodic lateral transport of suspended particles in midwater sediment plumes, described as intermediate nepheloid layers, which are associated with pycnoclines in the midwater column (Durrieu de Madron et al., 1999; Oliveira et al., 2002). The processes of downward particle flux and lateral particle flux are discussed in Sections 5.2 and 5.3.

\subsection{Seasonal variations in planktic foraminiferal test flux}

PF fluxes correspond well to the temporal succession of total standing stocks of PF analyzed from seasonal plankton tows at Station WH (Retailleau et al., 2009). Corresponding seasonal changes in standing stocks and test fluxes at 800 and $1700 \mathrm{~m}$ indicate that the seasonal flux signal recorded at depth originated from seasonal PF production in the overlying water column. Highest PF production was related to spring phytoplankton production (Retailleau et al., 2009). High primary production in surface waters was supported by maximum abundances of the planktic foraminiferal species Globigerina bulloides and Neogloboquadrina incompta in the trap samples at both water depths (Figs. 2 and 3). Both species are regarded as typical indicators of an enhanced availability of food (e.g. Hemleben et al., 1989; Marchant et al., 1998, 2004; Mohtadi et al., 2009; Thiede, 1975).

From late summer to early fall, PF flux at both trap depths, 800 and $1700 \mathrm{~m}$, decreased and remained low in fall and winter, following a decrease in the production of PF in surface waters. A decrease of PF numbers from the spring through the summer is also shown by total PF standing stocks in the surface ocean, and was related to a low in phytoplankton production from summer through fall (Longhurst, 2007). Limited PF production and low corresponding PF

Table 4

Comparison of averaged daily fluxes of planktic foraminifera in hemipelagic and open ocean regions of the world oceans.

\begin{tabular}{|c|c|c|c|c|c|}
\hline Hemipelagic sites & Water Depth (m) & Sampling period & Test Size $(\mu \mathrm{m})$ & $\begin{array}{l}\text { Average PF test } \\
\text { Flux } \mathrm{m}^{-2} \mathrm{~d}^{-1}\end{array}$ & Reference \\
\hline Bay of Biscay & 800 & June 2006-June 2007 & $>150$ & 278 & This study \\
\hline \multirow{2}{*}{$\begin{array}{l}\text { (Transitional NE } \\
\text { Atlantic) }\end{array}$} & 1700 & June 2006-June 2007 & & 326 & \\
\hline & 1700 & June 2007-June 2008 & & 362 & \\
\hline $\begin{array}{l}\text { Canary Islands } \\
\text { (Subtrop. NE Atl.) }\end{array}$ & 700 & Jan.1997-Sept.1997 & $>125$ & 277 & Abrantes et al. (2002) \\
\hline \multicolumn{6}{|l|}{ Hemipelagic upwelling regions } \\
\hline Pacific Ocean- & 890 & Dec.1979-Dec.1980 & $>125$ & 1234 & Thunell et al. (1983) \\
\hline \multirow{2}{*}{ Panama Basin } & 2590 & & & 1192 & \\
\hline & 3560 & & & 1554 & \\
\hline $\begin{array}{l}\text { Pacific Ocean off } \\
\text { California }\end{array}$ & 480 & Jan.1988-July 1988 & $>125$ & 4000 & Thunell and Sautter (1992) \\
\hline $\begin{array}{l}\text { Pacific Ocean off } \\
\text { Peru }\end{array}$ & 2300 & July 1993-July 1994 & $>150$ & 4000 & Marchant et al. (1998) \\
\hline Indian Ocean off & 830 & Dec.2000-Nov.2001 & $>150$ & 545 & Mohtadi et al. (2009) \\
\hline \multirow[t]{2}{*}{ Indonesia } & 830 & Dec.2001-Nov.2002 & & 963 & \\
\hline & 600 & Nov.2002-July 2003 & & 440 & \\
\hline \multicolumn{6}{|l|}{ Open ocean sites } \\
\hline \multirow[t]{4}{*}{ Central Pacific (east of Hawaii) } & 978 & Sept.1978-Oct.1978 & $>100$ & 312 & Thunell and Honjo (1981) \\
\hline & 2778 & & & 430 & \\
\hline & 4280 & & & 292 & \\
\hline & 5582 & & & 157 & \\
\hline Tropical Atlantic & 389 & Dec.1977-Feb.1978 & $>100$ & 681 & Thunell and Honjo (1981) \\
\hline \multirow{3}{*}{ (Demarara abyssal plain) } & 988 & & & 655 & \\
\hline & 3755 & & & 717 & \\
\hline & 5068 & & & 260 & \\
\hline $\begin{array}{l}\text { Sargasso Sea } \\
\quad \text { (Subtropical Gyre) }\end{array}$ & 2200 & April 1978-May 1984 & $>125$ & 273 & Deuser and Ross (1989) \\
\hline Canary Islands & 500 & Jan.1997-Sept.1997 & $>125$ & 166 & Abrantes et al. (2002) \\
\hline $\begin{array}{l}\text { (Subtropical NE } \\
\text { Atlantic) }\end{array}$ & 900 & Jan.1997-Oct.1997 & & 121 & \\
\hline Transitional NE Atl. $\left(47^{\circ} \mathrm{N}, 20^{\circ} \mathrm{W}\right)$ & 2000 & September 1996 & $>100$ & 4500 & Schiebel (2002) \\
\hline $\begin{array}{l}\text { Walvis Ridge } \\
\text { (Transitional SE Atl.) }\end{array}$ & 2450 & Mar.2000-August 2000 & $>150$ & 163 & Lončarić et al. (2007) \\
\hline Azores Front & 2000 & March 2002-April 2003 & $>125$ & 429 & Storz et al. (2009) \\
\hline Azores Front & 3000 & March 2002-April 2003 & & 464 & \\
\hline Madeira Basin & 3000 & May 2003-April 2004 & & 96 & \\
\hline
\end{tabular}


flux during the summer are associated with depletion of nutrients and food in surface waters, caused by strong thermal stratification. The change in hydrographic and trophic conditions in surface waters was also recorded by a significant decrease in the relative abundance of Globigerina bulloides, while Neogloboquadrina incompta became dominant in summer (Figs. 2 and 3). The faunal changes are in good agreement with studies at the pelagic BIOTRANS site located in the eastern North Atlantic $\left(47^{\circ} \mathrm{N}, 20^{\circ} \mathrm{W}\right)$, where a dominance of $N$. incompta occurred during reduced availability of nutrients and prey after spring production (Schiebel and Hemleben, 2000).

In fall, low PF flux at Station WH and low PF abundance in the overlying water column contrast with the increased fall phytoplankton production typical at mid-latitudes (Marquis et al., 2007). However, plankton production in fall is, in general, considerably slower and more sporadic than in spring (Laborde et al., 1999; Labry et al., 2004), and could thus explain slow PF production in surface waters and diminished PF flux at depths. During winter, phytoplankton production in the Bay of Biscay is generally slow (Antoine et al., 1996), and PF fluxes to the shallower trap consequently remained slow due to a low availability of PF alimentation in surface waters. At the deeper trap, PF fluxes showed a stepwise increase towards spring, mainly caused by increasing abundances in Neogloboquadrina incompta and Globigerina bulloides (Fig. 3).

According to our data, the downward PF flux from the surface waters to the intermediate to deep-water column is characterized by an intermittent signal, reflecting the seasonal PF production at the ocean surface. Therefore, seasonal PF fluxes are supposed to be mainly related to food availability (and subsequent PF production) in surface waters, and thus are closely linked to the primary production in the Bay of Biscay.

\subsection{Lateral advection}

Apart from the clear seasonal flux pattern caused by surface water planktic foraminiferal production and subsequent settling, the presence of benthic foraminifera and ${ }^{210} \mathrm{~Pb}$ data (F/P ratio) indicate lateral supply of particles including PF tests to both traps at $800 \mathrm{~m}$ and $1700 \mathrm{~m}$ water depth. In addition, total mass flux at the 1700-m trap was higher (except in May 2007) than at the 800-m trap. The temporal and vertical decoupling of lateral mass-flux events sampled by both the $800-\mathrm{m}$ and $1700-\mathrm{m}$ sediment traps indicates that the two traps were affected by different sedimentation processes, which could have been related to the different water masses and their different hydrodynamic processes.

At $1700 \mathrm{~m}$, more than half of the sampling intervals were characterized by an $\mathrm{F} / \mathrm{P}$ ratio $>1$, indicating frequent perturbations of the downward flux by lateral input of particles (Fig. 3). Sporadic increases in F/P ratios are ascribed to the temporary intensive lateral transport of suspended particles (Schmidt et al., 2009). During these periods, the total PF fluxes at $1700 \mathrm{~m}$ exceeded those at $800 \mathrm{~m}$ (e.g. December 2006 and March 2007). Consequently, although the PF fluxes at $1700 \mathrm{~m}$ exhibited an obvious seasonal signal, they were also quantitatively affected by strong lateral advection.

Although sediment trap data from different years exhibit interannual variability in PF production (e.g. Schiebel and Hemleben, 2000), and are hence not unequivocally comparable, an influence of lateral advection may explain differences in PF flux during the peak flux events in July 2006, spring 2007, and spring 2008 (Figs. 2 and 3 ). Consequently, the downward PF flux signal recorded in spring was augmented by a lateral flux of particles, and should not be considered to quantitatively mirror the primary flux signal, i.e., surface ocean production of particles.

Previous sediment trap studies in the Cap-Ferret canyon (Fig. 1) have shown that the development of intermediate nepheloid layers appears to play an important role in the dispersion of particulate matter on the continental margin in the Bay of Biscay (Durrieu de Madron et al., 1999; Heussner et al., 1999; Radakovitch and Heussner, 1999).
Durrieu de Madron et al. (1999) identified a surface nepheloid layer that evenly covered the shelf and slope region, and two intermediate nepheloid layers (INLs) detached from the continental slope at the shelf-break depth and around a depth of $500 \mathrm{~m}$. We suggest that during our trap experiment, at least two midwater sediment plumes (INLs) existed at different depths, and contributed to the particle flux intercepted by both traps: a particle-rich layer above $800 \mathrm{~m}$ depth affecting the upper trap, and a deeper particle-rich layer between 800 and $1700 \mathrm{~m}$ depth affecting the deeper trap. Propagation of these two INLs could have occurred at the upper and lower boundary of the MOW, at $600 \mathrm{~m}$ and $1300 \mathrm{~m}$, respectively.

\subsection{Origin and formation of lateral flux}

On the basis of annual mean ${ }^{210} \mathrm{~Pb}$ activity in traps located in the Cap-Ferret Canyon (Fig. 1), two particle sources were identified by Radakovitch and Heussner (1999). The first source located in the surficial water layers provides notably biogenic particles. The second source, most probably located in deeper water layers between 380 and $1350 \mathrm{~m}$, is composed of resuspended particles from upper slope sediments. Our data confirm the second source. The shallower of the two midwater sediment plumes ( $<800 \mathrm{~m}$ depth) affecting the upper trap in May 2007, contained resuspended material from the outer shelf and upper slope as indicated by a large number of benthic foraminifera typical of the adjacent outer shelf and upper slope (Duchemin et al., 2007; Fontanier et al., 2002, 2003, 2006). Benthic foraminifera were earlier sampled by plankton tows and sediment traps above the shelf break and continental slope, however they were considered resuspended and transported from the shelf by storm waves in the southern Middle Atlantic Bight (Brunner and Biscaye, 1997, 2003), and from shallow environments by waves and strong tidal currents (Murray et al., 1982; English channel).

The effect of internal tidal waves impinging on the continental slope was discussed for their potential role in resuspending sediments and generating intermediate nepheloid layers along the gently sloping open slope of the Plateau des Landes (Fig. 1) (Durrieu de Madron et al., 1999). Reworking of sediments from the upper slope is possible from internal tide propagation and dispersion of the tidal energy within the Bay of Biscay. As shown in Fig. 5, tidal energy rays reach the Plateau des Landes at a low angle, between $500 \mathrm{~m}$ and $800 \mathrm{~m}$ water depth. Tidal energy, brushing tangentially against the sea floor, produces constantly high shear stress at the sea floor and subsequent sediment reworking, introducing resuspended surface sediments including benthic foraminiferal tests into the bottom nepheloid layer. Possible changes in temporal variability of the tidal energy ray propagation could result from seasonal changes in the hydrographic structure.

Because of the stratification of the water column, fluids and associated particles in the bottom layer may be transported along a surface of stable water density that intersects the sloping bottom (Durrieu de Madron et al., 1999; Oliveira et al., 2002). Following this assumption, detachment and isopycnal dispersion of an intermediate nepholoid layer would be possible at the top of the MOW, and then feed the 800-m trap (Fig. 1b and $\mathrm{c}$ ).

Associated with specific hydrographical conditions, such as fronts, storms, and the Iberian Poleward Current, eddies may intermittently detach from the slope and drift offshore (Le Cann et al., 2010; Pingree and Le Cann, 1992; Somavilla et al., 2009). The Bay of Biscay is known to be an area dominated by intermittent mesoscale eddy activity (Pingree and Le Cann, 1992), which is confirmed by the weak timeaveraged circulation measured at both trap levels with respect to its long-period perturbations (Table 3). Following Le Cann et al. (2010), eddies in the Bay of Biscay are 50-70 km in diameter, and move slowly westward at $1-2 \mathrm{~km} \mathrm{~d}^{-1}$. They may exist up to $10-12$ months and extend from the surface down to approximately $800 \mathrm{~m}$ water depth. These eddies may affect the dispersion of detached particle-rich layers. 


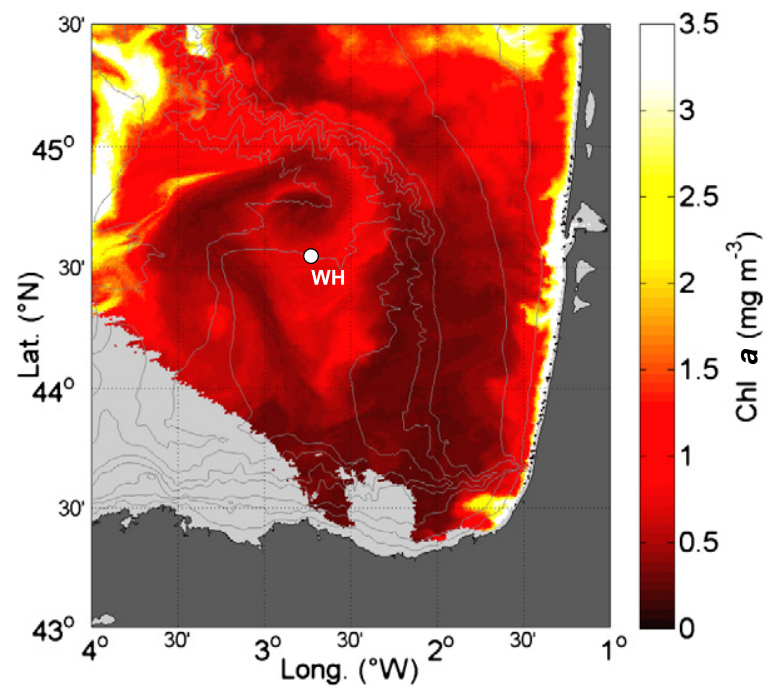

Fig. 6. Satellite image (Aqua MODIS) of the SE Bay of Biscay from April 2006, showing changing chlorophyll- $a$ concentration over an eddy close to Station WH (http:// oceancolor.gsfc.nasa.gov/). A colour version of this figure is available online.

Eddies located close to the $\mathrm{WH}$ mooring site can be recognized from satellite images of surface chlorophyll-a concentration (Fig. 6).

Periods of significant mesoscale hydrographical activity were observed at $800 \mathrm{~m}$ depth from current meter data as a sudden acceleration and change in current direction from the SW towards the NNW in May 2007 (Fig. 4b). We presume that eddies can transport particles already in suspension within the bottom nepheloid layer, and transfer them to the midwater column of the central Bay of Biscay at a current velocity of $0.15 \mathrm{~m} / \mathrm{s}$ measured at $800 \mathrm{~m}$. We suspect that such a process was responsible for the lateral advection observed at $800 \mathrm{~m}$ at station $\mathrm{WH}$ in May 2007, when no noticeable change in flux occurred deeper at the $1700 \mathrm{~m}$ level.

Frequent lateral advection events of variable intensity affected the lower trap, indicating a complex hydrographic structure in the deeper water column at Station WH, which is still not completely understood. Tidal energy might have been the most important hydrographical forcing at $1700 \mathrm{~m}$ depth, with a strong signal in power-spectral densities (Fig. 4b), indicating that the amplification of the internal tidal amplitude is stronger at the $1700-\mathrm{m}$ than at $800-\mathrm{m}$ trap. Such a focussing of tidal energy was also described by Gardner (1989) in the Baltimore deep-sea canyon, producing periodic resuspension of particulate matter.

Currents were on average weaker at the 1700-m trap than at the 800- $\mathrm{m}$ trap, and current directions differed between the two traps (Fig. 4c and d). In addition, mass flux events were temporally decoupled between the two trap records. In summary, current patterns and decoupling of particle flux events indicate independent developments of midwater sediment plumes which affect the $1700-\mathrm{m}$ and $800-\mathrm{m}$ traps.

Stratification of the water column due to the incursion of MOW between $600 \mathrm{~m}$ and $1300 \mathrm{~m}$ water depth (Fig. 1b) in the Bay of Biscay could explain the decoupling of the lateral flux between trap depths at Station WH. From our data, it is impossible, though, to either trace the exact origin of the advected particulate matter (sediment particles, including planktic and benthic foraminifera) or to quantify the magnitude of lateral advection relative to downward flux. However, our results suggest that the seasonal surface production of biogenic particulate matter may be qualitatively preserved but quantitatively modulated by hydrographic structures such as stratification of the upper water column, eddies, slope currents, or internal tidal energy.

\section{Conclusions}

Time-series sediment trap analyses of planktic foraminiferal (PF) tests and current velocities in the hemipelagic south-eastern Bay of
Biscay at the French continental margin reveal interfering downward and lateral particulate flux, due to (1) seasonal PF production in surface waters, and (2) subsurface hydrography, sediment reworking, and lateral advection of particles. Both processes need therefore to be considered when assessing production and transport of planktic foraminiferal tests, and other particulate matter to the deep ocean in hemipelagic regions.

Major changes in PF fluxes to the deep ocean reflect changes in the seasonal production of planktic foraminifera in the hemipelagic Bay of Biscay, and are closely coupled to seasonal changes in trophic conditions at the surface ocean. Seasonality in PF flux is pronounced in the trap at $800 \mathrm{~m}$ water depth. However, in regions affected by intense and sporadic mesoscale hydrographic activity, PF flux could be quantitatively modified by dilution from laterally advected particles.

Seasonality in particle flux is less well pronounced at $1700 \mathrm{~m}$ than at $800 \mathrm{~m}$ water depth. Fluxes at $1700 \mathrm{~m}$ are higher and more variable than at $800 \mathrm{~m}$ water depth. Sporadic increases in PF tests, which occur mainly during the winter along with the input of BF tests and enhanced $\mathrm{F} / \mathrm{P}$ ratios $\left({ }^{210} \mathrm{~Pb}\right.$ data), are indicative of frequent lateral advection at $1700 \mathrm{~m}$. Decoupled mass flux and PF fluxes between sediment traps at $800 \mathrm{~m}$ and $1700 \mathrm{~m}$ suggest that stratification of the water column and the evolution of midwater sediment plumes detaching from the shelf-break and upper continental slope affect particle flux dynamics. Possible energy sources for offshore transport of particles and consequent lateral advection at depth are hydrological structures such as eddies. Energy sources for sediment resuspension are tidal energy rays, which reach the shelf edge and upper continental slope of the south-eastern Bay of Biscay at a low angle.

\section{Acknowledgements}

We gratefully acknowledge the crew of the R/V Côtes de la Manche and the engineers of the Technical Department INSU for their help in installation and recovery of the mooring. We thank Sophie Terrien for technical assistance. Joanna Waniek and Juliane Brust from the IOW (Baltic Sea Research Institut Warnemünde, Germany) are acknowledged for providing the satellite-derived ocean productivity and sea surface temperature data. This study is part of the French FORCLIM Project and financially supported by the ANR (Agence Nationale de la Recherche, France). A two year post-doc fellowship was provided to Tanja Kuhnt by the Council of the Vendée Department. Two anonymous reviewers are acknowledged, whose comments improved the previous version of the manuscript considerably.

\section{Appendix A. Supplementary data}

Supplementary data to this article can be found online at doi:10. 1016/j.jmarsys.2011.11.026.

\section{References}

Abrantes, F., Meggers, H., Nave, S., Bollmann, J., Palma, S., Sprengel, C., Henderiks, J., Spies, A., Salgueiro, E., Moita, T., Neuer, S., 2002. Fluxes of micro-organisms along a productivity gradient in the Canary Islands region $\left(29^{\circ} \mathrm{N}\right)$ : implications for paleoreconstructions. Deep-Sea Res. II 49, 3599-3629.

Antoine, D., André, J.M., Morel, A., 1996. Oceanic primary production. 2. Estimation at global scale from satellite (coastal zone colour scanner) chlorophyll. Global Biogeochem. Cycles 10 (1), 57-70.

Bárcena, M.A., Flores, J.A., Sierro, F.J., Pérez-Folgado, M., Fabres, J., Calafat, A., Canals, M., 2004. Planktonic response to main changes in the Alboran Sea (Western Mediterranean) as documented in sediment traps and surface sediments. Mar. Micropaleontol. 53, 423-445.

Bé, A.W., 1960. Ecology of recent planktic foraminifera. Part 2: Bathymetric and seasonal distribution in the Sargasso Sea off Bermuda. Micropaleontology 6 (4), 373-392.

Bé, A.W., 1977. An ecological, zoogeographic and taxonomic review of recent planktic foraminifera. In: Ramsay, A.T.S. (Ed.), Oceanic Micropaleontology. Academic Press London, New York, San Francisco, pp. 733-808.

Bé, A.W., Tolderlund, D.S., 1971. Distribution and Ecology of Living Planktonic Foraminifera. Surface Waters of the Atlantic and Indian Oceans. Cambridge University Press, London, pp. 105-149. 
Beaufort, L., Heussner, S., 2001. Seasonal dynamics of calcareous nannoplankton on a West European continental margin: the Bay of Biscay. Mar. Micropaleontol. 43, 27-55.

Biscaye, P.E., Anderson, R.F., Deck, B.L., 1988. Fluxes of particles and constituents to the eastern United States continental slope and rise: SEEP-I. Cont. Shelf Res. 8 (5-7), 855-904.

Biscaye, P.E., Anderson, R.F., Deck, B.L., 1994. Fluxes of particulate matter on the slope of the southern middle Atlantic Bight: SEEP-II. Deep-Sea Res. II 41, 459-509.

Brunet, R.-C., Astin, K.B., 1999. Spatio-temporal variation in some physical and chemical parameters over a 25-year period in the catchment of the river Adour. J. Hydrol. 220, 209-221.

Brunner, C.A., Biscaye, P.E., 1997. Storm-driven transport of foraminifers from the shelf to the upper continental slope, southern Middle Atlantic Bight. Cont. Shelf Res. 17, 491-508.

Brunner, C.A., Biscaye, P.E., 2003. Production and resuspension of planktonic foraminifers at the shelf break of the Southern Middle Atlantic Bight. Deep-Sea Res. I 50, 247-268.

Cochran, J.K., McKibbin-Vaughan, T., Dornblaser, M.M., Hirschberg, D., Livingston, H.D. Buesseler, K.O., 1990. ${ }^{210} \mathrm{~Pb}$ scavenging in the North Atlantic and North Pacific Oceans. Earth Planet. Sci. Lett. 97, 332-352.

Coynel, A., Etcheber, H., Abril, G., Maneux, E., Dumas, J., 2005. Contribution of small mountainous rivers to particulate carbon input in the Bay of Biscay. Biogeochemistry 74 (2), 151-171.

Deuser, W.G., Ross, E.H., 1989. Seasonally abundant planktonic foraminifera of the Sargasso Sea: Succession, deep-water fluxes, isotopic compositions, and paleoceanographic implications. J. Foramin. Res. 19 (4), 268-293.

Deuser, W.G., Ross, E.H., Hemleben, C., Spindler, M., 1981. Seasonal changes in species composition, numbers, mass, size, and isotopic compositions of planktic foraminifera settling into the deep Sargasso Sea. Palaeogeogr. Palaeoclimatol. Palaeoecol. 33, 103-127.

Duchemin, G., Fontanier, C., Jorissen, F.J., Barras, C., Griveaud, C., 2007. Living small-sized $(63-150 \mu \mathrm{m})$ foraminifera from the mid-shelf to mid-slope environments in the Bay of Biscay. J. Foramin. Res. 37, 12-32.

Durrieu de Madron, X., Castaing, P., Nyffeler, F., Courp, T., 1999. Slope transport of suspended particulate matter on the Aquitanian margin of the Bay of Biscay. Deep-Sea Res. II 46, 2003-2027.

Fairbanks, R.G., Sverdlove, M.S., Free, R., Wiebe, P.H., Bé, A.W., 1982. Vertical distribution and isotopic fractionation of living planktonic foraminifera from the Panama Basin. Nature 298, 841-844.

Fernandez, E., Bode, A., Botas, A., Anadon, R., 1991. Microplankton assemblages associated with saline fronts during a spring bloom in the central Cantabrian Sea: differences in trophic structure between water bodies. J. Plankton Res. 13 (6), 1239-1256.

Fernandez, E., Boyd, P., Holligan, P.M., Harbour, D.S., 1993. Production of organic and inorganic carbon within large-scale coccolithophore bloom in the northeastern Atlantic Ocean. Mar. Ecol. Prog. Ser. 9, 271-285.

Fontanier, C., Jorissen, F.J., Licari, L., Alexandre, A., Anschutz, P., Carbonel, A., 2002. Live benthic foraminiferal faunas from the Bay of Biscay: faunal density, composition, and microhabitats. Deep-Sea Res. I 49, 751-785

Fontanier, C., Jorissen, F.J., Chaillou, G., David, C., Anschutz, P., Lafon, V., 2003. Seasonal and interannual variability of benthic foraminiferal faunas at $550 \mathrm{~m}$ depth in the Bay of Biscay. Deep-Sea Res. I 50, 457-494.

Fontanier, C. Jorissen, FJ., Anschutz, P., Chaillou, G., 2006. Seasonal variability of benthic foraminiferal faunas at $1000 \mathrm{~m}$ depth in the Bay of Biscay. J. Foramin. Res. 36, 61-76.

Froidefond, J.M., Castaing, P., Jouanneau, J., Froidefond, J.M., Castaign, P., Jouanneau, M., 1996. Distribution of suspended matter in a coastal upwelling area. Satellite data and in situ measurements. J. Mar. Syst. 8, 91-105.

Froidefond, J.M., Lavender, S.J., Laborde, P., Herbland, A., Lafon, V., 2002. SeaWiFS data interpretation in a coastal area in the Bay of Biscay. Int. J. Remote. Sens. 23 (5), 881-904.

Gardner, W.D., 1989. Periodic resuspension in Baltimore Canyon by focusing of intemal waves. J. Geophys. Res. 94 (C12), 18185-18194.

Gil, J., Sanchez, R., 2000. The importance of the main external driving agents in the Bay of Biscay hydrographic changes. Océanographie du Golfe de Gascogne, VIIème colloque international, 4-6 avril 2000, Biarritz, France, book of abstract, pp. 43-48.

Haynes, R., Barton, E.D., 1990. A poleward flow along the Atlantic coast of the Iberian Peninsula. J. Geophys. Res. 95 (C7), 11415-11441.

Hemleben, Ch., Spindler, M., Anderson, O.R., 1989. Modern Planktonic Foraminifera. Springer Verlag, Berlin.

Heussner, S., Durrieu de Madron, X., Radakovitch, O., Beaufort, L., Biscaye, P.E., Carbonne, J., Delsaut, N., Etcheber, H., Monaco, A., 1999. Spatial and temporal patterns of downward particle fluxes on the continental slope of the Bay of Biscay (northeastern Atlantic). Deep-Sea Res. II 46, 2101-2146.

Honjo, S., Manganini, S.J., 1993. Annual biogenic particle fluxes to the interior of the North Atlantic Ocean; studied at $34^{\circ} \mathrm{N} 21^{\circ} \mathrm{W}$ and $48^{\circ} \mathrm{N} 21^{\circ} \mathrm{W}$. Deep-Sea Res. 40 (1/2), 587-607.

Hwang, J., Manganini, S.J., Montluçon, D.B., Elington, T.I., 2009. Dynamics of particle export on the Northwest Atlantic margin. Deep-Sea Res. I 56, 1792-1803.

Kucera, M., 2007. Planktonic foraminifera as tracers of past oceanic environments. In: Hillaire-Marcel, C., de Vernal, A. (Eds.), Proxies in late Cenozoic paleoceanography: Developments in Marine Geology, 1, pp. 213-262.

Laborde, P., Urrutia, J., Valencia, V., 1999. Seasonal variability of primary production in the Cap-Ferret Canyon area (Bay of Biscay) during the ECOFER cruises. Deep-Sea Res. II 46, 2057-2079.

Labry, C., Delmas, D., Herbland, A., 2004. Phytoplankton and bacterial alkaline phosphatase activities in relation to phosphate and DOP availability within the Gironde plum waters (Bay of Biscay). J. Exp. Mar. Biol. Ecol. 318 (2), 213-225.

Lampert, L., Queguiner, B., Labasque, T., Pichon, A., Lebreton, N., 2002. Spatial variability of phytoplankton composition and biomass on the eastern continental shelf of the
Bay of Biscay (north-east Atlantic Ocean). Evidence for a bloom of Emiliania huxleyi (Prymnesiophyceae) in spring 1988. Cont. Shelf Res. 22, 1225-1247.

Lazure, P., Jegou, A.M., 1998. 3D modelling of seasonal evolution of Loire and Gironde plumes on Bay of Biscay continental shelf. Oceanol. Acta 21 (2), 165-177.

Le Cann, B., Serpette, A., Miller, P., 2010. Three cyclonic eddies in the Bay of Biscay in 2005-2006. Int. Symp. on Oceanography of the Bay of Biscay, ISOBAY 12, Brest France, book of abstract, pp. 133-134.

Le Corre, P., Tréguer, P., 1976. Caractéristiques chimiques et planctoniques du Golfe de Gascogne et du Proche Atlantique. Campagne POLYGAS A (20.10 au 04.11.1972) et PHYGAS 32 (24.04 au 08.05.1973). Résultats des campagnes "a la mer CNEXO 9 306.

Lončarić, N., van Iperen, J., Kroon, D., Brummer, G.J.A., 2007. Seasonal export and sediment preservation of diatomaceous, foraminiferal and organic matter mass fluxes in a trophic gradient across the SE Atlantic. Prog. Oceanogr. 73, 27-59.

Longhurst, A., 2007. Ecological geography of the sea, 2nd ed. Academic Press, Elsevier. (542 pp.).

Marchant, M., Hebbeln, D., Wefer, G., 1998. Seasonal flux patterns of planktic foraminifera in the Peru-Chile Current. Deep-Sea Res. I 45, 1161-1185.

Marchant, M., Hebbeln, D., Giglio, S., Coloma, C., Gonzaléz, H.E., 2004. Seasonal and interannual variability in the flux of planktic foraminifera in the Humboldt Current System off central Chile ( $30^{\circ} \mathrm{S}$ ). Deep-Sea Res. II 51, 2441-2455.

Marquis, E., Niquil, N., Delmas, D., Hartmann, H.J., Bonnet, D., Carlotti, F., Herbland, A., Labry, C., Sautour, B., Laborde, P., Vèzina, A., Dupuy, C., 2007. Inverse analysis of the planktonic food web dynamics related to phytoplankton bloom development on the continental shelf of the Bay of Biscay, French coast. Estuar. Coast. Shelf Sci. 73, 223-235.

Mohtadi, M., Steinke, S., Groeneveld, J., Fink, H.G., Rixen, T., Hebbeln, D., Donner, B. Herunadi, B., 2009. Low-latitude control on seasonal and interannual changes in planktonic foraminiferal flux and shell geochemistry off south Java: A sediment trap study. Paleoceanography 24, PA1201. doi:10.1029/2008PA001636.

Muhammad, Z., Bentley, S.J., Febo, L.A., Droxler, A.W., Dickens, G.R., Peterson, L.C., Opdyke B.N., 2008. Excess ${ }^{210} \mathrm{~Pb}$ inventories and fluxes along the continental slope and basins of the Gulf of Papua. J. Geophys. Res. 113. doi:10.1029/2006JF000676.

Murray, J.W., Sturrock, S., Weston, J., 1982. Suspended load transport of foraminiferal tests in a tide- and wave-swept sea. J. Foramin. Res. 12, 51-65.

Obata, A., Ishizaka, J., Endoh, M., 1996. Global verification of critical depth theory for phytoplankton bloom with climatological in situ temperature and satellite ocean color data. J. Geophys. Res. 101 (C9), 20657-20667.

Oliveira, A., Vitorino, J., Rodrigues, A., Jouanneau, J.M., Dias, J.A., Weber, O., 2002. Nepheloid layer dynamics in the northern Portuguese shelf. Prog. Oceanogr. 52 (2-4), 195-213.

Ortiz, J.D., Mix, A.C., Collier, R.W., 1995. Environmental control of living symbiotic and asymbiotic foraminifera of the California Current. Paleoceanography 10, 987-1009.

Pingree, R.D., Le Cann, B., 1990. Structure, strength and seasonality of the slope currents in the Bay of Biscay region. J. Mar. Biol. Assoc. UK 70 (4), 857-885.

Pingree, R.D., Le Cann, B., 1992. Anticyclonic slope water oceanic EDDIES (SWODDIES) in the Southern Bay of Biscay. Deep-Sea Res. 39, 1147-1175.

Puillat, I., Lazure, P., Jégou, A.M., Lampert, L., Miller, P.I., 2004. Hydrographical variability on the French continental shelf in the Bay of Biscay, during the 1990s. Cont. Shelf Res. 24 1143-1163.

Radakovitch, O., Heussner, S., 1999. Fluxes and budget of ${ }^{210} \mathrm{~Pb}$ on the continental margin of the Bay of Biscay (northeastern Atlantic). Deep-Sea Res. II 46, 2175-2203.

Retailleau, S., Howa, H., Schiebel, R., Lombard, F., Eynaud, F., Schmidt, S., Jorissen, F. Labeyrie, L., 2009. Planktic foraminiferal production along an offshore-onshore transect in the south-eastern Bay of Biscay. Cont. Shelf Res. 29 (8), 123-1135.

Reynolds, S.L., Thunell, R., 1989. Seasonal succession of planktonic foraminifera: results from a four-year time-series sediment trap experiment in the Northeast Pacific. J. Foramin. Res. 19, 253-267.

Schäfer, J., Blanc, G., Lapaquellerie, Y., Maillet, N., Maneux, E., Etcheber, H., 2002. Ten-year observation of the Gironde tributary fluvial system: fluxes of suspended matter, particulate organic carbon and cadmium. Mar. Chem. 79, 229-242.

Schiebel, R., 2002. Planktic foraminiferal sedimentation and the marine calcite budget Global Biogeochem. Cycles 16 (4), 1065-1076.

Schiebel, R., Hemleben, C., 2000. Interannual variability of planktic foraminiferal populations and test flux in the Eastern North Atlantic (JGOFS). Deep-Sea Res. 47, 1809-1852.

Schiebel, R., Hemleben, C., 2005. Modern planktic foraminifera. Paläontol. Z. 79 (1), 135-148

Schmidt, S., Howa, H., Mouret, A., Lombard, F., Anschutz, P., Labeyrie, L., 2009. Particle fluxes and recent sediment accumulation on the Aquitanian margin of Bay of Biscay. Cont. Shelf Res. 29, 1044-1052.

Somavilla, R., González Pola, C., Rodriguez, C., Josey, S.A., Sánchez, R.F., Lavín, A., 2009 Large changes in the hydrographic structure of the Bay of Biscay after the extreme mixing of winter 2005. J. Geophys. Res. 114, C01001. doi:10.1029/2008JC004974.

Storz, D., Schulz, H., Waniek, J.J., Schulz-Bull, D.E., Kučera, M., 2009. Seasonal and interannua variability of the planktic foraminiferal flux in the vicinity of the Azores Current. DeepSea Res. I 56, 107-124.

Thiede, J., 1975. Distribution of foraminifera in coastal waters of an upwelling area. Nature 253, 712-714.

Thomsen, L., Van Weering, T.C.E., 1998. Spatial and temporal variability of particulate matter in the benthic boundary layer at the N.W. European Continental Margin (Goban Spur). Prog. Oceanogr. 42 (1-4), 61-76.

Thunell, R.C., Honjo, S., 1981. Planktonic foraminiferal flux to the deep ocean: Sediment trap results from the tropical Atlantic and the central Pacific. Mar. Geol 40 (3-4), 237-253.

Thunell, R.C., Honjo, S., 1987. Seasonal and interannual changes in planktonic foraminiferal production in the North Pacific. Nature 328, 335-337.

Thunell, R.C., Sautter, L.R., 1992. Planktonic foraminiferal faunal and stable isotopic indices of upwelling: a sediment trap study in the San Pedro Basin, Southern California Bight 
In: Summerhayes, C.P., et al. (Ed.), Upwelling systems: evolution since the early Miocene: Geological Society, London, Special Publication, 64, pp. 77-91.

Thunell, R.C., Curry, W.B., Honjo, S., 1983. Seasonal variation in the flux of planktonic foraminifera: time series sediment trap results from the Panama Basin. Earth Planet. Sci. Lett. 64 (1), 44-55.

Tolderlund, D.S., Bé, A.W., 1971. Seasonal distribution of planktonic foraminifera in the western North Atlantic. Micropaleontology 17 (3), 297-329.
Tréguer, P., Le Corre, P., Grall, J.R., 1979. The seasonal variations of nutrients in the upper waters of the Bay of Biscay region and their relation to phytoplanctonic growth. Deep-Sea Res. 26 (10A), 1121-1152.

van Aken, H.M., 2000. The hydrology of the mid-latitude Northeast Atlantic Ocean II: the intermediate water masses. Deep-Sea Res. I 47, 789-824.

Wollast, R., Chou, L., 2001. Ocean Margin Exchange in the northerns Gulf of Biscay: OMEX I. An introduction. Deep-Sea Res. II 48, 2971-2978. 